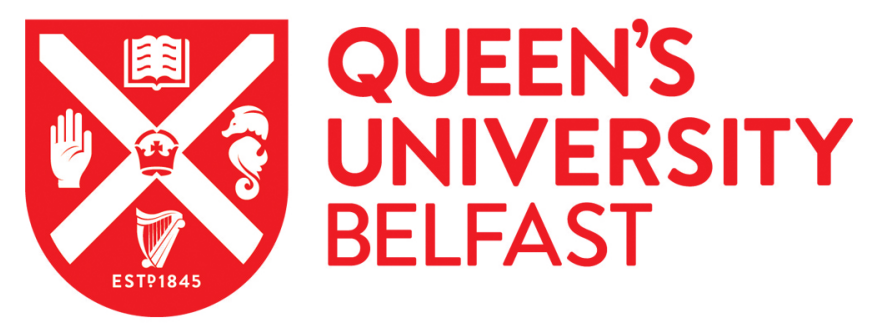

\title{
Synthesis of Piano Stool Complexes Employing the Pentafluorophenyl Substituted Diphosphine (C6F5)2PCH2P(C6F5)2 and the Effect of Phosphine Modifiers on Hydrogen Transfer Catalysis.
}

Marr, A., Saunders, G., Nieuwenhuyzen, M., \& Pollock, C. (2007). Synthesis of Piano Stool Complexes Employing the Pentafluorophenyl Substituted Diphosphine (C6F5)2PCH2P(C6F5)2 and the Effect of Phosphine Modifiers on Hydrogen Transfer Catalysis. Organometallics, 26(10)(10), 2659-2671.

https://doi.org/10.1021/om070089i

\section{Published in:}

Organometallics

Queen's University Belfast - Research Portal:

Link to publication record in Queen's University Belfast Research Portal

\section{General rights}

Copyright for the publications made accessible via the Queen's University Belfast Research Portal is retained by the author(s) and / or other copyright owners and it is a condition of accessing these publications that users recognise and abide by the legal requirements associated with these rights.

Take down policy

The Research Portal is Queen's institutional repository that provides access to Queen's research output. Every effort has been made to ensure that content in the Research Portal does not infringe any person's rights, or applicable UK laws. If you discover content in the

Research Portal that you believe breaches copyright or violates any law, please contact openaccess@qub.ac.uk. 


\title{
Synthesis of Piano Stool Complexes Employing the Pentafluorophenyl-Substituted Diphosphine $\left(\mathbf{C}_{6} \mathbf{F}_{5}\right)_{2} \mathbf{P C} \mathbf{H}_{2} \mathbf{P}\left(\mathbf{C}_{6} \mathbf{F}_{5}\right)_{2}$ and the Effect of Phosphine Modifiers on Hydrogen Transfer Catalysis
}

\author{
Andrew C. Marr,* Mark Nieuwenhuyzen, Ciara L. Pollock, and Graham C. Saunders \\ School of Chemistry and Chemical Engineering, Queen's University Belfast, David Keir Building, \\ Belfast, BT9 5AG, United Kingdom
}

Received January 30, 2007

\begin{abstract}
Ruthenium, rhodium, and iridium piano stool complexes of the pentafluorophenyl-substituted diphosphine $\left(\mathrm{C}_{6} \mathrm{~F}_{5}\right)_{2} \mathrm{PCH}_{2} \mathrm{P}\left(\mathrm{C}_{6} \mathrm{~F}_{5}\right)_{2}(2)$ have been prepared and structurally characterized by single-crystal $\mathrm{X}$-ray diffraction. The $\eta^{5},{ }_{,} P-\mathrm{Cp}-\mathrm{P}$ tethered complex $\left[\left\{\left(\eta^{5},{ }_{,} P-\mathrm{C}_{5} \mathrm{Me}_{4} \mathrm{CH}_{2} \mathrm{C}_{6} \mathrm{~F}_{4}-2-\mathrm{P}\left(\mathrm{C}_{6} \mathrm{~F}_{5}\right) \mathrm{CH}_{2} \mathrm{P}\left(\mathrm{C}_{6} \mathrm{~F}_{5}\right)_{2}\right\}-\right.\right.$ $\mathrm{RhCl}_{2}$ ] (9), in which only one phosphorus is coordinated to the rhodium, was prepared by thermolysis of a slurry of $[\mathrm{Cp} * \mathrm{RhCl}(\mu-\mathrm{Cl})]_{2}$ and $\mathbf{2}$ and was structurally characterized by single-crystal X-ray diffraction. The tethering occurs by intramolecular dehydrofluorinative coupling of the $\eta^{5}$-pentamethylcyclopentadienyl ligand and $\kappa P, \kappa P$-coordinated 2 . The geometric changes that occur on tethering force dissociation of one of the phosphorus atoms. The effects of introducing phosphine ligands to the coordination sphere of piano stool hydrogen transfer catalysts have been studied. The complexes of fluorinated phosphine complexes are found to transfer hydrogen at rates that compare favorably with leading catalysts, particularly when the phosphine and cyclopentadienyl functionalities are tethered. The highly chelating $\eta^{5}, \kappa P, \kappa L$ $\mathrm{Cp}-\mathrm{PP}$ complex $\left[\left(\eta^{5}, \kappa P, \kappa P-\mathrm{C}_{5} \mathrm{Me}_{4} \mathrm{CH}_{2}-2-\mathrm{C}_{5} \mathrm{~F}_{3} \mathrm{~N}-4-\mathrm{PPhCH}_{2} \mathrm{CH}_{2} \mathrm{PPh}_{2}\right) \mathrm{RhCl}_{\mathrm{B}} \mathrm{BF}_{4}\right.$ (1) was found to outperform all other complexes tested. The mechanism of hydrogen transfer catalyzed by piano stool phosphine complexes is discussed with reference to the trends in activity observed.
\end{abstract}

\section{Introduction}

Transfer hydrogenation is defined as the reduction of an unsaturated substrate with hydrogen derived from a reductant other than hydrogen gas. The substrates are most commonly ketones or imines and the hydrogen donor a secondary alcohol or formic acid. During the past decade this reaction has become one of the major transition-metal-mediated transformations in organic synthesis. This success can be attributed to the combination of synthetic usefulness and ease of operation. Transfer hydrogenation has been the subject of recent book chapters $^{1,2}$ and reviews. ${ }^{3-9}$ An iridium hydride complex was the first reported transition metal catalyst employed for the transfer of hydrogen. ${ }^{10,11}$ Soon afterward it was found that simple phosphine complexes of ruthenium and rhodium, such as $\left[\mathrm{RuCl}_{2^{-}}\right.$ $\left.\left(\mathrm{PPh}_{3}\right)_{3}\right]^{12}$ and $\left[\mathrm{RhCl}\left(\mathrm{PPh}_{3}\right)_{3}\right],{ }^{13-17}$ are also active catalysts,

* Corresponding author. E-mail: a.marr@qub.ac.uk.

(1) Gladiali, S.; Alberico, E. In Transition Metals for Organic Synthesis, 2nd ed.; Beller, M., Bolm, C., Eds.; Wiley-VCH: New York, 2004, Vol. 2, p 145.

(2) Gladiali, S.; Mestroni, G. In Transition Metals for Organic Synthesis, 1st ed.; Beller, M., Bolm, C., Eds.; Wiley-VCH: New York, 1998; p 97.

(3) Gladiali, S.; Alberico, E. Chem. Soc. Rev. 2006, 35, 226.

(4) Samec, J. S. M.; Bäckvall, J. E.; Andersson, P. G.; Brandt, P. Chem. Soc. Rev. 2006, 35, 237.

(5) Clapham, S. E.; Hadzovic, A.; Morris, R. H. Coord. Chem. Rev. 2004, $248,2201$.

(6) Blaser, H. U.; Malan, C.; Pugin, B.; Spindler, F.; Steiner, H.; Studer, M. Adv. Synth. Catal. 2003, 345, 103.

(7) Bäckvall, J. E. J. Organometal. Chem. 2002, 652, 105.

(8) Palmer, M. J.; Wills, M. Tetrahedron: Asymmetry 1999, 10, 2045.

(9) Zassinovich, G.; Mestroni, G.; Gladiali, S. Chem. Rev. 1992, 92, 1051.

(10) Trocha, J.; Henbest, H. B. Chem. Commun. 1967, 545.

(11) Henbest, H. B. Proc. Chem. Soc. 1964, 361.

(12) Sasson, Y.; Blum, J. J. Org. Chem. 1975, 40, 1887.

(13) Chowdhury, R. L.; Bäckvall, J. E. Chem. Commun. 1991, 1063. particularly in the presence of base. An extensive role for aromatic facially capping ligands, such as $\eta^{5}$-pentamethylcyclopentadienyl $\left(\mathrm{Cp}^{*}\right)$ and $\eta^{6}-p$-cymene ligands, has resulted from the ability of these spectator ligands to boost the enantioselectivity of the reaction. The high stereoselectivities achieved for the hydrogenation of alkyl aryl ketones using arene ruthenium catalysts have been attributed to the stabilizing interaction of the capping group with the aryl functionality of the ketone in the transition state. ${ }^{18} \mathrm{Cp}^{*}$ rhodium(III) complexes have been commercially exploited for the asymmetric transfer hydrogen of aryl alkyl ketones. ${ }^{19}$ More recently Wills and co-workers have demonstrated that tethering the amine to the aryl group of a hydrogen transfer catalyst can lead to an increase in catalyst stability and activity and improved enantioselectivity. ${ }^{20-22}$

The two main classes of mechanism quoted for transitionmetal-catalyzed hydrogen transfer are the inner sphere hydridic route and the metal-ligand bifunctional route. ${ }^{23}$ Examples of these mechanisms are given in Schemes 1 and 2. Hydridic

(14) Müller, D.; Umbricht, G.; Weber, B.; Pfaltz, A. Helv. Chim. Acta 1991, 74, 232.

(15) Gladiali, S.; Chelucci, G.; Chessa, G.; Delogu, G.; Soccolini, F. J. Organomet. Chem. 1987, 327, C15.

(16) Kvintovics, P.; James, B. R.; Heil, B. Chem. Commun. 1986, 1810. (17) Gladiali, S.; Pinna, L.; Delogu, G.; de Martin, S.; Zassinovich, G.; Mestroni, G. Tetrahedron Asymmetry 1990, 1, 635.

(18) Noyori, R.; Yamakawa, M.; Hashiguchi, S. J. Org. Chem. 2001, 66, 7931.

(19) Blacker, A. J.; Mellor, B. J. (Zeneca Ltd.) WO9842643, 1998.

(20) Matharu, D. S.; Morris, D. J.; Clarkson, G. J.; Wills, M. Chem. Commun. 2006, 3232.

(21) Cheung, F. K.; Hayes, A. M.; Hannedouche, J.; Yim, A. S. Y.; Wills, M. J. Org. Chem. 2005, 70, 3188 .

(22) Cross, D. J.; Houson, I.; Kawamoto, A. M.; Wills, M. Tetrahedron Lett. 2004, 45, 843 .

(23) Noyori, R; Hashiguchi, S. Acc. Chem. Res. 1997, 30, 97. 
Scheme 1. Monohydride Inner Sphere Mechanism for Hydrogen Transfer from a Secondary Alcohol to a Ketone (M is a transition metal complex)

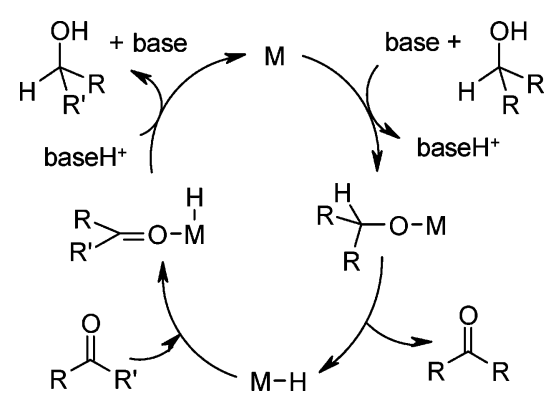

for example acetophenone / 1-phenyl ethanol<smiles>CC(O)c1ccccc1</smiles>

Scheme 2. Metal-Ligand Bifunctional Outer-Sphere Mechanism for Hydrogen Transfer from a Secondary Alcohol to a Ketone

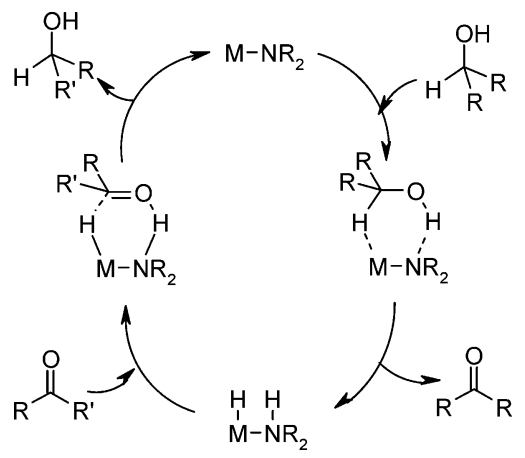

Scheme 3. Formation of Cp-PL Ligands by Intramolecular Dehydrofluorinative Coupling

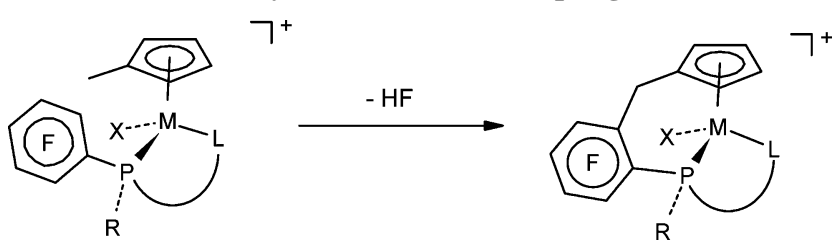

Hydrogen transfer is extremely important in biology, as the redox processes that fuel life are controlled by passing protons and electrons down electron transport chains, thus separating the primary oxidant and reductant and releasing the energy of reaction slowly. Thus the reduction of cofactors such as nicotinamide adenine dinucleotide $\left(\mathrm{NAD}^{+}\right)$by hydrogen transfer from organic chemicals is key to life. Hembre and co-workers ${ }^{27}$ have demonstrated that $[\mathrm{Cp} * \mathrm{Ru}(\kappa P, \kappa P$-dppm $)(\mathrm{H})]$ and $[\mathrm{Cp} * \mathrm{Ru}-$

mechanisms are expected for catalysts derived from metal phosphine complexes such as $\left[\mathrm{RhCl}\left(\mathrm{PPh}_{3}\right)_{3}\right]$ (Scheme 1). Addition of a ligand containing a Brønsted base, such as DPEN (1,2-diphenylethylenediamine), to a piano stool complex such as cymene ruthenium chloride, $\left[\left(\eta^{6}-p \text {-cymene }\right) \mathrm{RuCl}(\mu-\mathrm{Cl})\right]_{2}$, allows the activation of the hydrogen donator by an alternative mechanism in which the metal and ligand act cooperatively (Scheme 2).

Recently new opportunities for the exploitation of hydrogen transfer chemistry have emerged. Among these are the use of racemization catalysts to facilitate dynamic kinetic resolution $(\mathrm{DKR})^{24,25}$ and the use of hydrogen transfer reactions to model and assist enzymes. ${ }^{26-28}$

In DKR a homogeneous catalyst can be exploited to improve the yield of a kinetic resolution. Bäckvall has reviewed the subject. $^{25}$ When an enantioselective biocatalytic reaction is carried out on a racemic mixture of a chiral alcohol, the maximum yield possible is $50 \%$. However, the addition of a hydrogen transfer catalyst that can racemize the alcohol increases this potential yield to $100 \%$. Although many catalysts for racemization are known, the operation of biological and chemical catalysis together has proven difficult and selectivies and activities of the resultant systems are often disappointing. One success in this area was the commercialization of the DKR of esters from racemic alcohols by the combination of racemization and lipase activity. ${ }^{29}$

(24) Dinh, P. M.; Howarth, J. A.; Hudnott, A. R.; Williams, J. M. J.; Harris, W. Tetrahedron Lett. 1996, 37, 762.

(25) (a) Pamies, O.; Bäckvall, J. E. Chem. Rev. 2003, 103, 3247. (b) Huerta, F. F.; Minidis, A. B. E.; Bäckvall, J. E. Chem. Soc. Rev. 2001, 30, 321.

(26) Hembre, R. T.; McQueen, S. J. Am. Chem. Soc. 1994, 116, 2141.

(27) Lutz, J.; Hollmann, F.; Vinh Ho, T.; Schnyder, A.; Fish, R. H.; Schmid, A. J. Organomet. Chem. 2004, 689, 4783.

(28) de Gonzalo, G.; Ottolina, G.; Carrea, G.; Fraaije, M. W. Chem. Commun. 2005, 3724.

(29) Verzijl, G. K. M.; de Vries, J. G. (DSM) WO0190396, 2001. $\left.(\kappa P, \kappa P-\mathrm{dppm})\left(\eta^{2}-\mathrm{H}_{2}\right)\right]^{+}(\mathrm{dppm}=$ bis(diphenylphosphino)methane) catalyze the reduction of the pyridinium $\mathrm{NAD}^{+}$model $N$-methylacridinium using hydrogen. $\left[\mathrm{Cp} * \mathrm{Rh}(\kappa N, \kappa N \text {-bpy) } \mathrm{H}]^{+}\right.$ (bpy $=2,2^{\prime}$-bipyridine) has been shown to catalyze the transfer of hydrogen from formic acid to the $\mathrm{NAD}^{+}$model $\mathrm{N}$-benzyl1,4-dihydronicotinamide and thus enable the cofactor-dependent biocatalytic hydroxylation of a hydroxybiphenyl to the corresponding catechol. ${ }^{28}$ Similarly $\left[\mathrm{Cp} * \mathrm{Rh}(\kappa N, \kappa N-b p y)\left(\mathrm{H}_{2} \mathrm{O}\right)\right]^{2+}$ has been used to transfer hydrogen from formate to flavin adenine dinucleotide (FAD) in order to assist the operation of monooxygenase enzymes in the absence of $\mathrm{NAD}^{+} .29$

In order to be used in the same pot as a biocatalyst, a chemical catalyst must be robust and its reactivity must be very specific so that no side reactions occur with the biopolymers, which contain enticing soft donor groups such as thiols and thiothers. It is important to engineer a metal center with a high degree of reactant specificity and a low tendency to undergo unwanted substitution reactions, and therefore the comparison of homogeneous catalysts for hydrogen transfer promoted by highly chelating ligands containing good donor atoms is pertinent. Ideally the active center should be protected inside an activating pocket similar to that observed at metalloenzyme active sites. Such a highly stable pocket is afforded by the tethered cyclopentadienyl ligands $\eta^{5}, \kappa P, \kappa P-\mathrm{Cp}-\mathrm{PP}$ and $\eta^{5}, \kappa P-\mathrm{Cp}-\mathrm{P}$ containing a $\kappa P, \kappa P$ - and $\kappa P$-coordinated diphosphine.

Previously reported $\left[\left(\eta^{5}, \kappa P, \kappa P-\mathrm{C}_{5} \mathrm{Me}_{4} \mathrm{CH}_{2} \mathrm{C}_{5} \mathrm{~F}_{3} \mathrm{~N}-2-\mathrm{PPhCH}_{2}-\right.\right.$ $\left.\mathrm{CH}_{2} \mathrm{PPh}_{2}\right) \mathrm{RhCl}_{\mathrm{BF}_{4}}{ }^{30}$ (1) was selected as the first potential catalyst. Compound $\mathbf{1}$ is readily prepared by the thermolysis reaction between $[\mathrm{Cp} * \mathrm{RhCl}(\mu-\mathrm{Cl})]_{2}$ and $\left(\mathrm{C}_{5} \mathrm{~F}_{4} \mathrm{~N}-4\right) \mathrm{PhPCH}_{2} \mathrm{CH}_{2}-$ $\mathrm{PPh}_{2}$, which involves intramolecular dehydrofluorinative coupling of the two coordinated ligands (Scheme 3 ). The chirality of this complex is advantageous, as it imparts the potential to

(30) Bellabarba, R. M.; Nieuwenhuyzen, M.; Saunders, G. C. Organometallics 2003, 22, 1802. 
be an asymmetric hydrogen transfer catalyst. Access to chiral complexes of $\eta^{5}, \kappa P-\mathrm{Cp}-\mathrm{P}$ ligands is more problematic. Previous routes have involved elaborate, multiple-step, low-yielding syntheses. ${ }^{31}$ Intramolecular dehydrofluorinative coupling has been used to prepare achiral complexes of $\eta^{5}, \kappa P-\mathrm{Cp}-\mathrm{P}$ ligands using monodentate phosphines, but the yields and purity are not as favorable as for reactions using chelating diphosphines. ${ }^{32}$ However, the convenience of intramolecular dehydrofluorinative coupling led us to examine other strategies. A chelating ligand is necessary for rapid and clean dehydrofluorinative coupling, but the product is a complex of a $\eta^{5}, \kappa P, \kappa L-C p-P L$ ligand. However, it may be possible to convert this to a $\eta^{5}, \kappa P-\mathrm{Cp}-\mathrm{P}$ ligand either by cleaving the PL linkage and removing $\mathrm{L}$ or by using geometric changes that occur on tethering to disfavor coordination of the L ligating group; if necessary, L can then be converted to a poorly coordinating group by functionalization. One group of chelating PL ligands that may partially dissociate on tethering are those that give small bite $(\mathrm{P}-\mathrm{M}-\mathrm{L})$ angles. It has been established that coupling of the phosphine to cyclopentadienyl reduces both the $\mathrm{Cp}-\mathrm{M}-\mathrm{P}$ angle and the $\mathrm{M}-\mathrm{P}$ bond length, ${ }^{30,32}$ which may constrain the geometry of the $\mathrm{Cp}-$ PL ligand sufficiently to force dissociation of the L functionality. Ethylene-bridged diphosphines favor chelation, giving bite angles of $>80^{\circ} .{ }^{33}$ In contrast, methylene-bridged diphosphines, $\mathrm{R}_{2} \mathrm{PCH}_{2} \mathrm{PR}_{2}$, either chelate to give strained four-membered rings with $\mathrm{P}-\mathrm{M}-\mathrm{P}$ bite angles of $\mathrm{ca} .72^{\circ} 33$ or bridge between two metals, depending on the nature of the substituent $\mathrm{R}$. The strain of the four-membered ring typically leads to the diphosphines bridging between metals, but sterically demanding substituents, such as tert-butyl and cyclohexyl, cause chelation to be favored. ${ }^{34,35}$ The dehydrofluorinative coupling reaction requires that at least one substituent be an aryl group bearing ortho fluorine atoms, and since fluorinated aryl groups are much more sterically demanding than the non-fluorinated analogues, ${ }^{36,37}$ the fluoro-substituted analogue of dppm, $\left(\mathrm{C}_{6} \mathrm{~F}_{5}\right)_{2} \mathrm{PCH}_{2} \mathrm{P}\left(\mathrm{C}_{6} \mathrm{~F}_{5}\right)_{2}$ (2), is an ideal candidate for the synthesis of $\eta^{5}, \kappa P-\mathrm{Cp}-\mathrm{P}$ complexes that are chiral by virtue of the coordinated phosphorus bearing four different substituents. These complexes fulfill the requirements of the second type of complex for our study. Comparisons of their catalytic activity with those of piano stool complexes of $\mathbf{2}$ would then provide useful insight into the effect of tethering on catalytic activity.

Here we report the syntheses of piano stool complexes of $\mathbf{2}$, and a $\eta^{5}, \kappa P-\mathrm{Cp}-\mathrm{P}$ complex derived from it, and the catalytic activities of a wide variety of phosphine-substituted piano stool complexes including $\mathbf{1}$ for hydrogen transfer reactions. We assess the new catalysts relative to important literature catalysts and demonstrate the excellent potential of $\eta^{5}$-Cp, $\kappa P, \kappa P$-diphosphine, $\eta^{5}, \kappa P-\mathrm{Cp}-\mathrm{P}$, and $\eta^{5}, \kappa P, \kappa P-\mathrm{Cp}-\mathrm{PP}$ complexes. Part of the synthetic work has been communicated. ${ }^{38}$

\section{Results and Discussion}

Synthesis and Structure of $\left(\mathrm{C}_{6} \mathrm{~F}_{5}\right)_{2} \mathrm{PCH}_{2} \mathrm{P}\left(\mathrm{C}_{6} \mathrm{~F}_{5}\right)_{2}$ (2). Diphosphine 2 was synthesized in $81 \%$ yield by addition of

(31) Butenschön, H. Chem. Rev. 2000, 100, 1527.

(32) Bellabarba, R. M.; Nieuwenhuyzen, M.; Saunders, G. C. Organometallics 2002, 21. 5726.

(33) Dierkes, P.; van Leeuwen, P. W. N. M. J. Chem. Soc., Dalton Trans. 1999, 1519.

(34) Puddephat, R. J. Chem. Soc. Rev. 1983, 12, 99.

(35) Eisenträger, F.; Göthlich, A.; Gruber, I.; Heiss, H.; Kiener, C. A.; Krüger, C.; Notheis, J. U.; Rominger, F.; Scherhag, G.; Schultz, M.; Straub, B. F.; Volland, M. A. O.; Hofmann, P. New J. Chem. 2003, 27, 540. (36) Tolman, C. A. Chem. Rev. 1977, 77, 313.

(37) White, D.; Colville, N. J. Adv. Organomet. Chem. 1994, 36, 95.

(38) Marr, A. C.; Nieuwenhuyzen, M.; Pollock, C. L.; Saunders, G. C. Inorg. Chem. Commun. 2006, 9, 407.
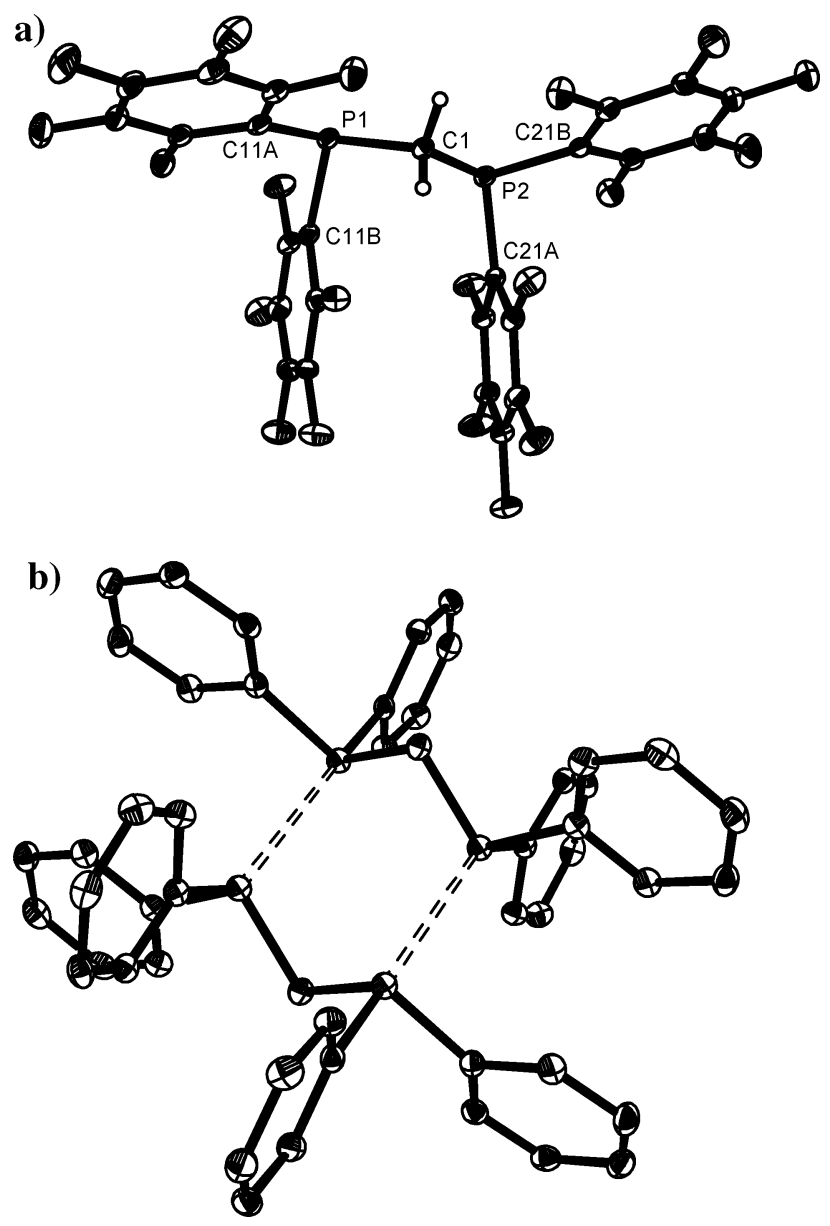

Figure 1. (a) Molecular structure of $\left(\mathrm{C}_{6} \mathrm{~F}_{5}\right)_{2} \mathrm{PCH}_{2} \mathrm{P}\left(\mathrm{C}_{6} \mathrm{~F}_{5}\right)_{2}, 2$. Thermal ellipsoids are at the $30 \%$ level. (b) View of the pairing of molecules of 2 . Thermal ellipsoids are at the $30 \%$ level. Hydrogen and fluorine atoms are omitted for clarity.

bis(dichlorophosphino)methane to pentafluorophenylmagnesium bromide. The structure of $\mathbf{2}$ (Figure 1) was determined by singlecrystal X-ray diffraction. Selected bond distances and angles of $\mathbf{2}$ are given in Table 1. Two of the pentafluorophenyl rings are approximately coplanar (deviation $8.9^{\circ}$ ) and twisted relative to the plane defined by $\mathrm{P}-\mathrm{C}-\mathrm{P}$ by ca. $35^{\circ}$. The planes of the other pair are approximately parallel (deviation $8.1^{\circ}$ ), with a separation of ca. $3.5 \AA$, and are virtually perpendicular $\left(83^{\circ}\right.$ to $\left.90^{\circ}\right)$ to those of the other rings. The latter aryl rings are positioned on the same side of the plane defined by $\mathrm{P}-\mathrm{C}-\mathrm{P}$. Although this arrangement is atypical of uncomplexed $\mathrm{Ar}_{2} \mathrm{PCH}_{2}-$ $\mathrm{PAr}_{2}$, it is common for metal complexes of dppm. ${ }^{39}$ The structure reveals an unprecedented arrangement comprising pairs

(39) For example: (a) Cowie, M.; Dickson, R. S. Inorg. Chem. 1981 20, 2682. (b) Mague, J. T. Inorg. Chem. 1983, 22, 45. (c) Delavaux, B.; Chaudret, B.; Taylor, N. J.; Arabi, S.; Poilblanc, R. J. Chem. Soc., Chem. Commun. 1985, 805. (d) Balch, A.; Waggoner, K. M.; Olmstead, M. M. Inorg. Chem. 1988, 27, 4511. (e) Kirss, R. U.; Eisenberg, R. Inorg. Chem. 1989, 28, 3372. (f) Knox, S. A. R.; Lloyd, B. R.; Morton, D. A. V.; Orpen, A. G.; Turner, M. L.; Hogarth, G. Polyhedron 1995, 14, 2723. (g) Wang, L.-S.; Cowie, M. Organometallics 1995, 14, 3040. (h) Cauzzi, D.; Graiff, C.; Lanfranchi, M.; Predieri, G.; Tiripicchio, A. J. Chem. Soc., Dalton Trans. 1995, 2321. (i) Alvarez, M. A.; Bois, C.; Garcia, M. E.; Riera, V.; Ruiz, M. A. Angew. Chem., Int. Ed. Engl. 1996, 35, 102. (j) Bruce, M. I.; Low, P. J.; Werth, A.; Skelton, B. W.; White, A. H. J. Chem. Soc., Dalton Trans. 1996, 1551. (k) Cotton, F. A.; Daniels, L. M.; Haefner, S. C.; Kuhn, F. E. Inorg. Chim. Acta 1999, 287, 159. (1) Qin, Z.; Jennings, M. C.; Puddephat, R. J. Inorg. Chem. 2001, 40, 6220. (m) Snaith, T. J.; Low, P. J.; Rousseau, R.; Puschmann, H.; Howard, J. A. K. J. Chem. Soc., Dalton Trans. 2001, 292. (n) Rowsell, B. D.; Trepanier, S. J.; Lam, R.; McDonald, R.; Cowie, M. Organometallics 2002, 21, 3228. 
Table 1. Selected Bond Lengths $(\AA)$ and Angles (deg) for 2

\begin{tabular}{lclr}
\hline $\mathrm{P}(1)-\mathrm{C}(1)$ & $1.845(2)$ & $\mathrm{P}(2)-\mathrm{C}(1)$ & $1.846(2)$ \\
$\mathrm{P}(1)-\mathrm{C}(11 \mathrm{~A})$ & $1.843(2)$ & $\mathrm{P}(1)-\mathrm{C}(11 \mathrm{~B})$ & $1.838(2)$ \\
$\mathrm{P}(2)-\mathrm{C}(21 \mathrm{~A})$ & $1.851(2)$ & $\mathrm{P}(2)-\mathrm{C}(21 \mathrm{~B})$ & $1.840(2)$ \\
$\mathrm{C}-\mathrm{C}$ & $1.369(3)-1.396(3)$ & $\mathrm{C}-\mathrm{F}$ & $1.340(2)-1.353(2)$ \\
$\mathrm{P}(1)-\mathrm{C}(1)-\mathrm{P}(2)$ & $106.46(10)$ & $\mathrm{C}(1)-\mathrm{P}(1)-\mathrm{C}(11 \mathrm{~A})$ & $104.17(9)$ \\
$\mathrm{C}(1)-\mathrm{P}(1)-\mathrm{C}(11 \mathrm{~B})$ & $101.94(10)$ & $\mathrm{C}(11 \mathrm{~A})-\mathrm{P}(1)-\mathrm{C}(11 \mathrm{~B})$ & $102.06(10)$ \\
$\mathrm{C}(1)-\mathrm{P}(2)-\mathrm{C}(21 \mathrm{~A})$ & $102.91(10)$ & $\mathrm{C}(1)-\mathrm{P}(2)-\mathrm{C}(21 \mathrm{~B})$ & $104.54(9)$ \\
$\mathrm{C}(21 \mathrm{~A})-\mathrm{P}(1)-\mathrm{C}(21 \mathrm{~B})$ & $98.58(9)$ & $\mathrm{C}(11 \mathrm{~A})-\mathrm{P}(1) \cdots \mathrm{P}(2)-\mathrm{C}(21 \mathrm{~A})$ & 75.5 \\
$\mathrm{C}(11 \mathrm{~A})-\mathrm{P}(1) \cdots \mathrm{P}(2)-\mathrm{C}(21 \mathrm{~B})$ & -48.1 & $\mathrm{C}(11 \mathrm{~B})-\mathrm{P}(1) \cdots \mathrm{P}(2)-\mathrm{C}(21 \mathrm{~A})$ & -27.8 \\
$\mathrm{C}(11 \mathrm{~B})-\mathrm{P}(1) \cdots \mathrm{P}(2)-\mathrm{C}(21 \mathrm{~B})$ & -151.4 & &
\end{tabular}

Table 2. Selected Bond Lengths (̊̊) and Angles (deg) for 5, 6, 8, and 9

\begin{tabular}{|c|c|c|c|c|c|c|}
\hline & 5 & {$[\mathrm{Cp} * \mathrm{RhCl}(\mathrm{dfppe})] \mathrm{BF}_{4}{ }^{48}$} & $6^{a}$ & {$[\mathrm{Cp} * \operatorname{IrCl}(\mathrm{dfppe})] \mathrm{BF}_{4}{ }^{\mathrm{r}}$} & $\mathbf{8} \cdot \mathrm{CH}_{2} \mathrm{Cl}_{2}$ & 9 \\
\hline $\mathrm{C}_{n}^{\dagger}-\mathrm{M}^{a}$ & $1.849(16)$ & $1.869(7)$ & $1.870(7)$ & $1.886(1)$ & $1.751(7)$ & $1.804(6)$ \\
\hline $\mathrm{M}-\mathrm{P}$ & $2.367(4)$ & $2.342(2)$ & $2.328(5)^{b}$ & $2.3278(14)$ & $2.2705(18)$ & $2.2624(10)$ \\
\hline & $2.386(4)$ & $2.362(2)$ & & $2.311(2)$ & $2.3454(18)$ & \\
\hline $\mathrm{M}-\mathrm{Cl}$ & $2.3998(13)$ & $2.380(2)$ & $2.399(7)$ & $2.3891(13)$ & $2.3819(17)$ & $\begin{array}{l}2.4085(16) \\
2.3952(16)\end{array}$ \\
\hline $\mathrm{P}-\mathrm{CH}_{2}$ & $1.837(14)$ & $1.825(6)$ & $1.845(14)^{b}$ & $1.832(6)$ & $1.835(7)$ & $1.842(5)$ \\
\hline & $1.854(15)$ & $1.830(7)$ & & $1.833(5)$ & $1.852(6)$ & $1.849(5)$ \\
\hline $\mathrm{C}_{n}^{\dagger}-\mathrm{M}-\mathrm{P}$ & $137.9(5)$ & $131.0(2)$ & $138.4(2)^{b}$ & $131.36(3)$ & $134.6(2)$ & $127.7(2)$ \\
\hline & $138.3(5)$ & 134.2(2) & & $133.97(4)$ & $140.0(2)$ & \\
\hline $\mathrm{C}_{n}^{\dagger}-\mathrm{M}-\mathrm{Cl}$ & $125.1(5)$ & $121.9(2)$ & $123.2(2)$ & $121.10(4)$ & $125.7(2)$ & $\begin{array}{l}123.8(2) \\
121.5(2)\end{array}$ \\
\hline $\mathrm{P}-\mathrm{M}-\mathrm{Cl}$ & $\begin{array}{l}80.03(14) \\
80.38(14)\end{array}$ & $\begin{array}{l}83.26(7) \\
85.36(7)\end{array}$ & $81.19(18)^{b}$ & $\begin{array}{l}85.46(5) \\
83.96(5)\end{array}$ & $\begin{array}{l}79.77(6) \\
82.40(6)\end{array}$ & $\begin{array}{l}90.73(6) \\
92.17(6)\end{array}$ \\
\hline $\mathrm{Cl}-\mathrm{M}-\mathrm{Cl}$ & & & & & & $90.88(5)$ \\
\hline $\mathrm{P}-\mathrm{M}-\mathrm{P}$ & 72.17(4) & $84.05(8)$ & 72.4(3) & $84.32(5)$ & $72.19(6)$ & \\
\hline $\mathrm{P}-\mathrm{C}-\mathrm{P}$ & $98.7(2)$ & & $96.3(10)$ & & $95.1(3)$ & $106.9(3)$ \\
\hline $\mathrm{M}-\mathrm{P}-\mathrm{CH}_{2}$ & $\begin{array}{l}93.9(4) \\
92.8(4)\end{array}$ & $\begin{array}{l}105.5(2) \\
109.5(2)\end{array}$ & $94.5(5)^{b}$ & $\begin{array}{l}106.4(2) \\
109.9(2)\end{array}$ & $\begin{array}{l}93.8(2) \\
96.8(2)\end{array}$ & $112.80(18)$ \\
\hline
\end{tabular}

${ }^{a} \mathrm{C}_{n}^{\dagger}$ represents the centroid of the $\eta^{5}$-cyclopentadienyl $\mathrm{C}_{5}$ or $\eta^{6}$-arene $\mathrm{C}_{6}$ ring. ${ }^{b} \mathbf{6}$ possesses a plane of symmetry defined by $\mathrm{Cp}^{\dagger}$, Ir, $\mathrm{Cl}$, and $\mathrm{B}$ leading to identical pairs of $\mathrm{Ir}-\mathrm{P}$ and $\mathrm{P}-\mathrm{CH}_{2}$ distances and $\mathrm{Cp}+-\mathrm{Ir}-\mathrm{P}, \mathrm{P}-\mathrm{Ir}-\mathrm{Cl}$, and $\mathrm{Ir}-\mathrm{P}-\mathrm{CH}_{2}$ angles.

of molecules (Figure 1) with short intermolecular P...P distances of $3.318 \AA\left(\sum\right.$ van der Waals' radii $\left.3.80 \AA^{40}\right)$. The $\mathrm{P}-\mathrm{C}$ distances and $\mathrm{P}-\mathrm{C}-\mathrm{P}$ angle are identical within $3 \sigma$ to those of dppm $\left(1.828(5)\right.$ to $1.868(5) \AA$ and $\left.106.2(3)^{\circ}\right) .^{41}$

As expected the ${ }^{31} \mathrm{P}\left\{{ }^{1} \mathrm{H}\right\}$ NMR spectrum of 2 displays a second-order pattern consistent with an $\left[\mathrm{A}[\mathrm{X}]_{4}[\mathrm{Y}]_{4}[\mathrm{Z}]_{2}\right]_{2}$ spin system centered at $\delta-52.1$. This value is similar to that of the ethylene-bridged analogue $\left(\mathrm{C}_{6} \mathrm{~F}_{5}\right)_{2} \mathrm{PCH}_{2} \mathrm{CH}_{2} \mathrm{P}\left(\mathrm{C}_{6} \mathrm{~F}_{5}\right)_{2}$ (dfppe) $(\delta$ $\left.-44.1^{42}\right)$. Unfortunately the complicated natures of the spin system and ${ }^{19} \mathrm{~F}$ NMR spectrum did not permit the coupling constants to be obtained by simulation.

An in situ NMR experiment indicated that monoxide, $\mathbf{3}$, and then dioxide, $\mathbf{4}$, were formed on addition of hydrogen peroxide to 2 . The identity of $\mathbf{4}$ was confirmed by mass spectrometry. As expected, the ${ }^{31} \mathrm{P}\left\{{ }^{1} \mathrm{H}\right\}$ NMR spectrum of $\mathbf{3}$ exhibited a doublet at $\delta 15.0\left({ }^{2} J_{\mathrm{PP}}=76 \mathrm{~Hz}\right)$, assigned to $\left(\mathrm{C}_{6} \mathrm{~F}_{5}\right)_{2} \mathrm{PO}$, and a doublet of quintets of quintets at $\delta-60.1$, assigned to $\left(\mathrm{C}_{6} \mathrm{~F}_{5}\right)_{2} \mathrm{P}$, and that of $\mathbf{4}$ exhibited a singlet at $\delta$ 8.9.

Synthesis and Structures of Piano Stool Complexes of 2. Treatment of $\left[\mathrm{Cp}^{*} \mathrm{MCl}(\mu-\mathrm{Cl})\right]_{2}(\mathrm{M}=\mathrm{Rh}$ or $\mathrm{Ir})$ with 2 equiv of 2 in the presence of tetrafluoroborate gave the yellow solids $[\mathrm{Cp} * \mathrm{MCl}(\kappa P, \kappa P-2)] \mathrm{BF}_{4}, 5(\mathrm{M}=\mathrm{Rh})$ and $\mathbf{6}(\mathrm{M}=\mathrm{Ir})$, in $92 \%$ and $66 \%$ yields, respectively. The salts $\left[\left(\eta^{6}\right.\right.$-arene $) \operatorname{RuCl}(\kappa P, \kappa P$ 2) $\mathrm{BF}_{4}(\mathbf{7}$, arene $=p$-cymene, 4 -isopropyltoluene; $\mathbf{8}$, arene $=$ mesitylene, $\left.\mathrm{C}_{6} \mathrm{Me}_{3}-1,3,5\right)$ were prepared similarly from $\left[\left(\eta^{6}-\right.\right.$ arene $) \mathrm{RuCl}(\mu-\mathrm{Cl})]_{2}$ and 2 in high yield. The ${ }^{1} \mathrm{H}$ and ${ }^{31} \mathrm{P}\left\{{ }^{1} \mathrm{H}\right\}$ NMR spectra of $\mathbf{5}$ and $\mathbf{6}$ are similar to those of $\left[\mathrm{Cp}^{*} \mathrm{MCl}(\kappa P, \kappa P-\right.$ dppm) $\mathrm{BF}_{4}\left(\mathrm{M}=\mathrm{Rh},{ }^{43} \mathrm{Ir}^{44,45}\right)$, but without phenyl hydrogen

(40) Bondi, A. J. Phys. Chem. 1964, 68, 441.

(41) Schmidbauer, H.; Reber, G.; Schier, A.; Wagner, F. E.; Müller, G. Inorg. Chim. Acta 1988, 147, 143.

(42) Cook, R. L.; Morse, J. G. Inorg. Chem. 1982, 21, 4103.

(43) Valderrama, M.; Contreras, R.; Bascuñan, M.; Alegria, S.; Boys, D. Polyhedron 1995, 14, 2239. resonances and with $\delta_{\mathrm{P}}$ at lower frequency by ca. $30 \mathrm{ppm}$. The values of $\delta_{\mathrm{P}}$ for $\mathbf{7}$ and $\mathbf{8}$ are at lower frequency to that of [ $\left(\eta^{6}-\right.$ $p$-cymene $) \operatorname{RuCl}(\kappa P, \kappa P$-dppm $)] \mathrm{BF}_{4}{ }^{46}$ by ca. $26 \mathrm{ppm}$. The ${ }^{19} \mathrm{~F}$ NMR spectra of salts 5-8 exhibit broadened signals for the ortho and meta fluorine resonances consistent with hindered rotation about the $\mathrm{P}-\mathrm{C}_{6} \mathrm{~F}_{5}$ bonds. From variable-temperature ${ }^{19} \mathrm{~F}$ NMR spectra values of the free energy of activation, $\Delta G^{\ddagger}$, for rotation about one pair of $\mathrm{P}-\mathrm{C}_{6} \mathrm{~F}_{5}$ bonds of $56 \pm 2$ and 54 $\pm 2 \mathrm{~kJ} \mathrm{~mol}^{-1}$ were calculated ${ }^{47}$ for 5 and $\mathbf{6}$, respectively, and a minimum value of $\Delta G^{\ddagger}$ of $61 \mathrm{~kJ} \mathrm{~mol}^{-1}$ was calculated ${ }^{47}$ for both 7 and 8 . The spectra did not allow calculation of $\Delta G^{\ddagger}$ for rotation about the other pair of $\mathrm{P}-\mathrm{C}_{6} \mathrm{~F}_{5}$ bonds.

The structures of $\mathbf{5}, \mathbf{6}$, and $\mathbf{8}$ were determined by single-crystal X-ray diffraction (Figures 2, 3, and 4). Selected bond distances and angles are given in Table 2. For comparison the pertinent data of the ethylene-bridged rhodium and iridium analogues ${ }^{48}$ are included. The cation of $\mathbf{5}$ is symmetric within $3 \sigma$ about the plane defined by $\mathrm{Cp}^{\dagger}, \mathrm{Rh}$, and $\mathrm{Cl}$, and that of 6 has crystallographically imposed symmetry about the plane defined by $\mathrm{Cp}^{\dagger}$, $\mathrm{Ir}$, and $\mathrm{Cl}$. In contrast the cation of $\mathbf{8}$ is not symmetric. The cations adopt the expected three-legged piano stool structures with similar $\mathrm{C}_{n}^{\dagger}-\mathrm{M}-\mathrm{Cl}\left(\mathrm{ca} .125^{\circ}\right)$ and $\mathrm{P}-\mathrm{M}-\mathrm{Cl}\left(79^{\circ}\right.$ to $\left.83^{\circ}\right)$ angles. The $C \mathrm{p}^{\dagger}-\mathrm{M}-\mathrm{P}$ angles of $\mathbf{5}$ and $\mathbf{6}$ are similar and are significantly larger than those of the ethylene-bridged analogues. The $\mathrm{P}-\mathrm{M}-\mathrm{P}$ bite angle is identical for the three cations and

(44) Gelabert, R.; Moreno, M.; Lluch, J. M.; Lledós, A.; Pons, V.; Heinekey, D. M. J. Am. Chem. Soc. 2004, 126, 8813.

(45) Valderrama, M.; Contreras, R. J. Organomet. Chem. 1996, 513, 7. (46) Daguenet, C.; Scopelliti, R.; Dyson, P. J. Organometallics 2004, 23,4849 .

(47) Sandström, J. Dynamic N.M.R. Spectroscopy; Academic Press: London, 1982.

(48) Atherton, M. J.; Fawcett, J.; Holloway, J. H.; Hope, E. G.; Karaçar, A.; Russell, D. R.; Saunders, G. C. J. Chem. Soc., Dalton Trans. 1996, 3215 . 


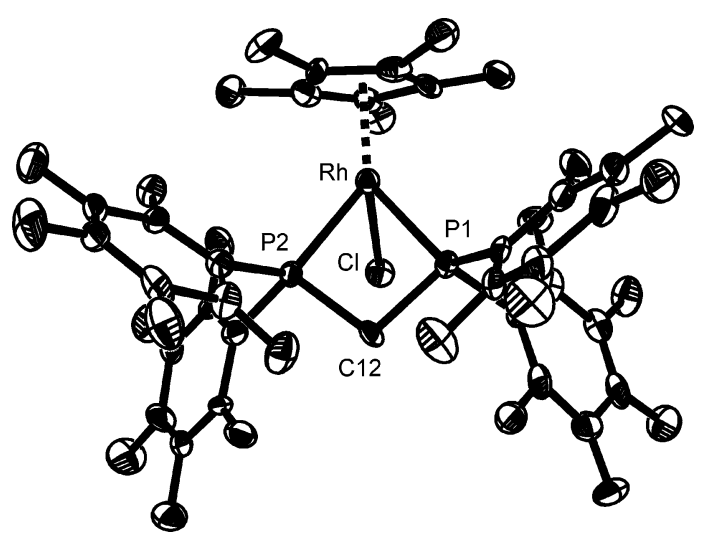

Figure 2. Structure of the cation of $\left[\mathrm{Cp} * \mathrm{RhCl}\left\{\kappa P, \kappa P-\left(\mathrm{C}_{6} \mathrm{~F}_{5}\right)_{2}-\right.\right.$ $\left.\left.\mathrm{PCH}_{2} \mathrm{P}\left(\mathrm{C}_{6} \mathrm{~F}_{5}\right)_{2}\right\}\right] \mathrm{BF}_{4}, \mathbf{5}$. Thermal ellipsoids are at the $30 \%$ level. Hydrogen atoms are omitted for clarity.

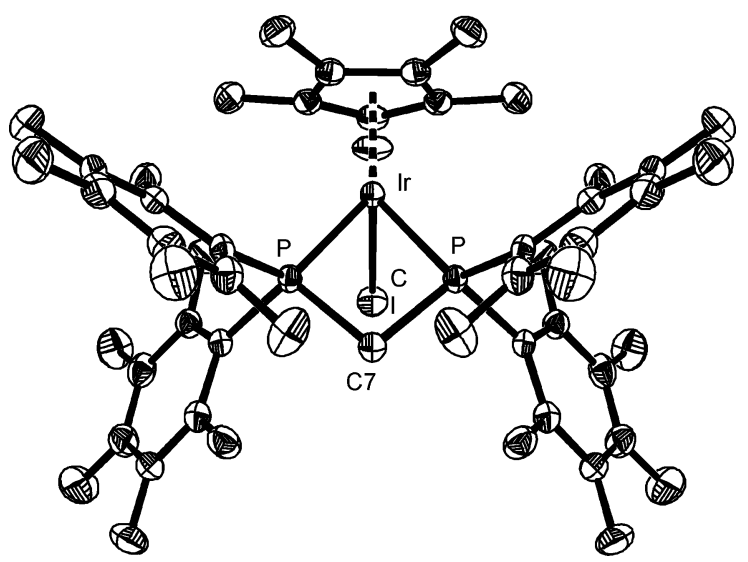

Figure 3. Structure of $\left[\mathrm{Cp} * \operatorname{IrCl}\left\{\kappa P, \kappa P-\left(\mathrm{C}_{6} \mathrm{~F}_{5}\right)_{2} \mathrm{PCH}_{2} \mathrm{P}\left(\mathrm{C}_{6} \mathrm{~F}_{5}\right)_{2}\right\}\right] \mathrm{BF}_{4}$, 6. Thermal ellipsoids are at the $30 \%$ level. Hydrogen atoms are omitted for clarity.

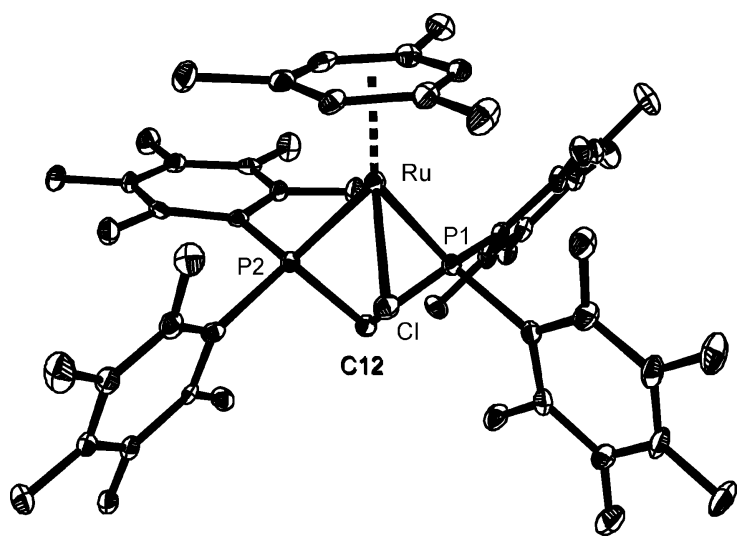

Figure 4. Structure of $\left[\left(\eta^{6}\right.\right.$-mesitylene $) \mathrm{RuCl}\left\{\kappa P, \kappa P-\left(\mathrm{C}_{6} \mathrm{~F}_{5}\right)_{2} \mathrm{PCH}_{2} \mathrm{P}-\right.$ $\left.\left.\left(\mathrm{C}_{6} \mathrm{~F}_{5}\right)_{2}\right\}\right] \mathrm{BF}_{4}, \mathbf{8}$. Thermal ellipsoids are at the $30 \%$ level. Hydrogen atoms are omitted for clarity.

similar to that of the three-legged piano stool complex of dppm $\left[\left(\eta^{6}-p\right.\right.$-cymene $) \mathrm{RuCl}(\kappa P, \kappa P$-dppm $\left.)\right] \mathrm{BF}_{4}\left(71.29(6)^{\circ}\right) .{ }^{46}$ This angle is $12^{\circ}$ smaller than those of the ethylene-bridged rhodium and iridium analogues $\left[\mathrm{Cp} * \mathrm{MCl}\left\{\kappa P, \kappa P-\left(\mathrm{C}_{6} \mathrm{~F}_{5}\right)_{2} \mathrm{PCH}_{2} \mathrm{CH}_{2} \mathrm{P}\left(\mathrm{C}_{6} \mathrm{~F}_{5}\right)_{2}\right\}\right]$ $\mathrm{BF}_{4}\left(\mathrm{M}=\mathrm{Rh} 84.05(8)^{\circ}, \mathrm{M}=\mathrm{Ir} 84.32(8)^{\circ}\right){ }^{48} \mathrm{The} \mathrm{Ir}-\mathrm{P}$ distance is shorter than the $\mathrm{Rh}-\mathrm{P}$ distances, which is consistent with the ethylene-bridged analogues. The asymmetry in the cation of $\mathbf{8}$ is reflected in the $\mathrm{Ar}^{\dagger}-\mathrm{M}-\mathrm{P}$ angles and $\mathrm{Ru}-\mathrm{P}$ distances. The former differ by ca. $5^{\circ}$ and the latter by ca. $0.07 \AA$. The mean $\mathrm{Ru}-\mathrm{P}$ distance $(2.308(2) \AA)$ is similar to the $\mathrm{Ru}-\mathrm{P}$ distances of $\left[\left(\eta^{6}-p\right.\right.$-cymene $) \mathrm{RuCl}(\kappa P, \kappa P$-dppm $\left.)\right] \mathrm{BF}_{4}(2.316(2)$ and 2.309(2) $\AA$ ). ${ }^{46}$ The $\mathrm{P}-\mathrm{CH}_{2}$ distances of the three cations

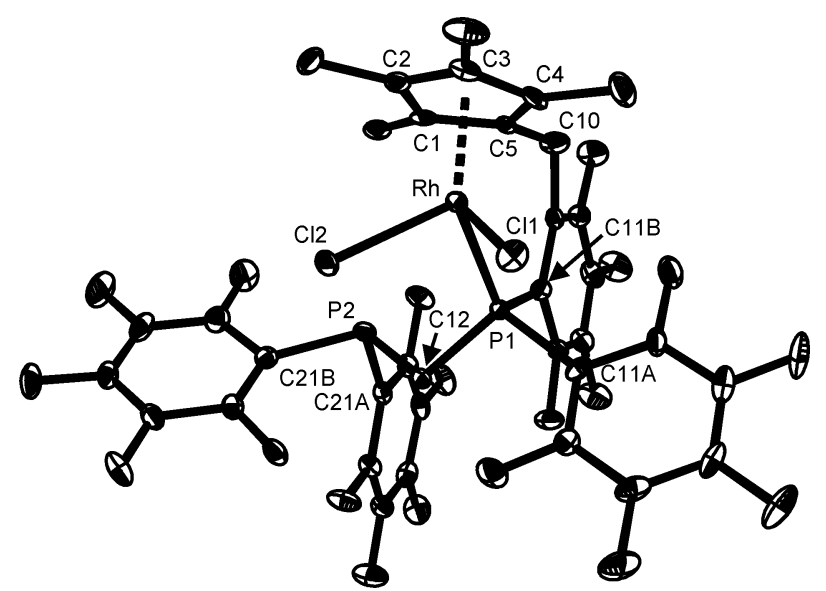

Figure 5. Structure of the $S$ enantiomer of $\left[\left\{\eta^{5}, \kappa P-\mathrm{C}_{5} \mathrm{Me}_{4} \mathrm{CH}_{2} \mathrm{C}_{6} \mathrm{~F}_{4}\right.\right.$ 2-P( $\left.\left.\left.\mathrm{C}_{6} \mathrm{~F}_{5}\right) \mathrm{CH}_{2} \mathrm{P}\left(\mathrm{C}_{6} \mathrm{~F}_{5}\right)_{2}\right\} \mathrm{RhCl}_{2}\right]$, 9. Thermal ellipsoids are at the $30 \%$ level. Hydrogen atoms are omitted for clarity.

are identical within $3 \sigma$, and the $\mathrm{P}-\mathrm{C}-\mathrm{P}$ angles are similar, but are at least $6^{\circ}$ more acute than that of $\mathbf{2}$. That of $\mathbf{8}$ is identical with that of $\left[\left(\eta^{6}-p\right.\right.$-cymene $) \operatorname{RuCl}(\kappa P, \kappa P$-dppm $\left.)\right] \mathrm{BF}_{4}{ }^{46}$

Thermolysis Reactions between $\left[\left(\eta^{n}-\mathrm{C}_{n} \mathbf{R}_{n}\right) \operatorname{MCl}(\mu-\mathrm{Cl})_{2}\right]_{2}$ and 2. The reaction between $\left[\mathrm{Cp}^{*} \mathrm{RhCl}(\mu-\mathrm{Cl})\right]_{2}$ and 2 equiv of 2 in refluxing benzene gave the singly linked neutral complex $\left[\left\{\eta^{5}, \kappa P-\mathrm{C}_{5} \mathrm{Me}_{4} \mathrm{CH}_{2} \mathrm{C}_{6} \mathrm{~F}_{4}-2-\mathrm{P}\left(\mathrm{C}_{6} \mathrm{~F}_{5}\right) \mathrm{CH}_{2} \mathrm{P}\left(\mathrm{C}_{6} \mathrm{~F}_{5}\right)_{2}\right\} \mathrm{RhCl}_{2}\right]$, 9, in $70 \%$ yield. Complex 9 was fully characterized by elemental analysis, mass spectrometry, and NMR spectroscopy, and its structure determined by single-crystal X-ray diffraction (Figure 5). The ${ }^{31} \mathrm{P}\left\{{ }^{1} \mathrm{H}\right\}$ NMR spectrum displays two mutually coupled resonances at $\delta 43.1$ and $-66.6\left({ }^{2} J_{\mathrm{PP}}=185 \mathrm{~Hz}\right)$. The former shows further coupling to rhodium $\left({ }^{1} J_{\mathrm{RhP}}=170 \mathrm{~Hz}\right)$ and the latter to fluorine $\left({ }^{3} J_{\mathrm{PF}}=38 \mathrm{~Hz}\right)$. The magnitude of ${ }^{2} J_{\mathrm{PP}}$ is significantly larger than that of $28.1 \mathrm{~Hz}$ reported for $\left[\mathrm{Cp} * \mathrm{RhCl}_{2}\left(\kappa P-\mathrm{Ph}_{2} \mathrm{PCH}_{2} \mathrm{PPh}_{2}\right)\right],{ }^{43}$ but is consistent with larger couplings occurring for more electronegative substituents. ${ }^{49}$ The ${ }^{19} \mathrm{~F}$ NMR spectrum exhibits 13 resonances integrating for 19 fluorine atoms and indicates hindered rotation about one $\mathrm{P}-\mathrm{C}_{6} \mathrm{~F}_{5}$ bond, presumably that of the phosphorus atom coordinated to rhodium, which is expected to be the most sterically crowded. $\Delta G^{\ddagger}$ was calculated ${ }^{47}$ to be $46 \pm 1 \mathrm{~kJ} \mathrm{~mol}^{-1}$ from variabletemperature spectra. The ${ }^{1} \mathrm{H}$ NMR spectrum exhibits resonances consistent with those of rhodium complexes in which a cyclopentadienyl ring is linked to a phosphine: two mutually coupled resonances, one also showing coupling to phosphorus, assigned to the hydrogen atoms of the methylene bridge, and four resonances, three of which possess coupling to one phosphorus atom, assigned to the methyl groups. ${ }^{30,32,50}$

Important bond distances and angles of $\mathbf{9}$ are given in Table 2. The $\mathrm{Rh}-\mathrm{P}$ distance and $\mathrm{Cp}^{\dagger}-\mathrm{Rh}-\mathrm{P}$ angle are consistent with those of rhodium complexes in which a cyclopentadienyl ring is linked to a phosphine by a tetrafluorobenzyl or similar group. ${ }^{30,32,50}$ The $\mathrm{Cp}^{\dagger}-\mathrm{Rh}-\mathrm{P}$ and $\mathrm{Cp}^{\dagger}-\mathrm{Rh}-\mathrm{Cl}$ angles are smaller than those of $\mathbf{5}$, and the $\mathrm{P}-\mathrm{Rh}-\mathrm{Cl}$ and $\mathrm{Cl}-\mathrm{Rh}-\mathrm{Cl}$ angles are close to $90^{\circ}$. Significantly the $\mathrm{Rh}-\mathrm{P}$ distance is 0.1 $\AA$ shorter than that of $\mathbf{5}$ and the $\mathrm{P}-\mathrm{C}-\mathrm{P}$ angle is identical to that of 2 .

Since $\left[\left\{\eta^{5}, \kappa P, \kappa P-\mathrm{C}_{5} \mathrm{Me}_{3}\left[\mathrm{CH}_{2} \mathrm{C}_{6} \mathrm{~F}_{4}-2-\mathrm{P}\left(\mathrm{C}_{6} \mathrm{~F}_{5}\right) \mathrm{CH}_{2}\right]_{2}-1,3\right\} \mathrm{RhCl}\right]^{+}$ is formed by thermolysis of $[\mathrm{Cp} * \mathrm{RhCl}(\mu-\mathrm{Cl})]_{2}$ and $\left(\mathrm{C}_{6} \mathrm{~F}_{5}\right)_{2} \mathrm{PCH}_{2}-$

(49) Finer, E. G.; Harris, R. K. Prog. Nucl. Magn. Reson. Spectrosc. 1971, 6, 61.

(50) (a) Atherton, M. J.; Fawcett, J.; Holloway, J. H.; Hope, E. G.; Karaçar, A.; Russell, D. R.; Saunders, G. C. J. Chem. Soc., Chem. Commun. 1995, 191. (b) Atherton, M. J.; Fawcett, J.; Holloway, J. H.; Hope, E. G.; Russell, D. R.; Saunders, G. C. J. Organomet. Chem. 1999, 582, 163. 
Scheme 4. "Clip on, Flip off" Reaction Scheme

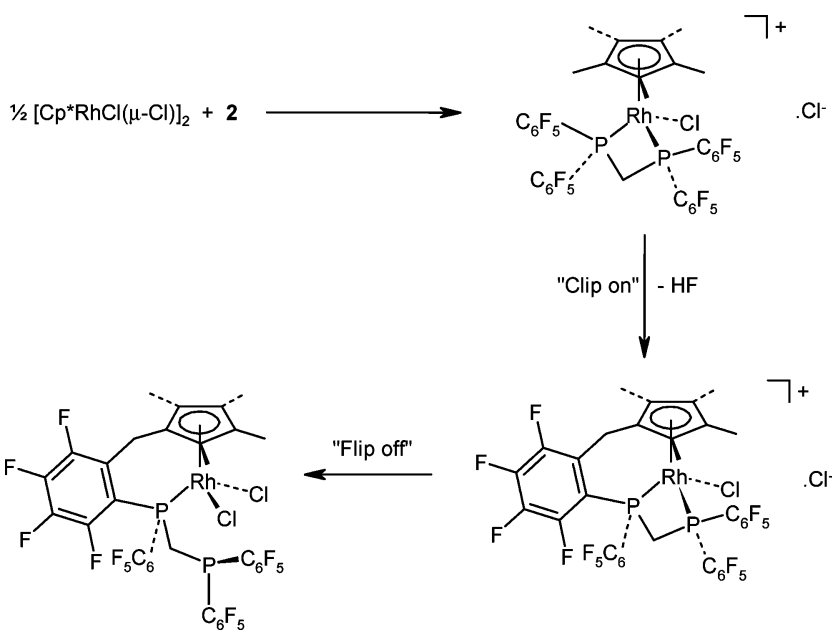

Table 3. Selected Bond Lengths (̊̊) and Angles (deg) for 11

\begin{tabular}{lclc}
\hline $\mathrm{Ru}(1)-\mathrm{P}(1)$ & $2.216(4)$ & $\mathrm{Ru}(1)-\mathrm{P}(2)$ & $2.222(4)$ \\
$\mathrm{Ru}(1)-\mathrm{Cl}(1)$ & $2.388(4)$ & $\mathrm{Ru}(1)-\mathrm{Cl}(2)$ & $2.470(4)$ \\
$\mathrm{Ru}(1)-\mathrm{Cl}(3)$ & $2.417(4)$ & $\mathrm{Ru}(1)-\mathrm{Cl}(4)$ & $2.489(4)$ \\
$\mathrm{P}(1)-\mathrm{C}(10)$ & $1.849(14)$ & $\mathrm{P}(2)-\mathrm{C}(10)$ & $1.796(15)$ \\
$\mathrm{Ar} r^{\dagger}-\mathrm{Ru}(2)^{a}$ & $1.643(16)$ & $\mathrm{Ru}(2)-\mathrm{Cl}(2)$ & $2.404(4)$ \\
$\mathrm{Ru}(2)-\mathrm{Cl}(3)$ & $2.474(4)$ & $\mathrm{Ru}(2)-\mathrm{Cl}(4)$ & $2.426(4)$ \\
$\mathrm{P}(1)-\mathrm{Ru}(1)-\mathrm{P}(2)$ & $74.01(15)$ & $\mathrm{P}(1)-\mathrm{Ru}(1)-\mathrm{Cl}(1)$ & $86.94(16)$ \\
$\mathrm{P}(1)-\mathrm{Ru}(1)-\mathrm{Cl}(2)$ & $178.21(15)$ & $\mathrm{P}(1)-\mathrm{Ru}(1)-\mathrm{Cl}(3)$ & $100.84(15)$ \\
$\mathrm{P}(1)-\mathrm{Ru}(1)-\mathrm{Cl}(4)$ & $102.85(15)$ & $\mathrm{P}(2)-\mathrm{Ru}(1)-\mathrm{Cl}(1)$ & $86.08(15)$ \\
$\mathrm{P}(2)-\mathrm{Ru}(1)-\mathrm{Cl}(2)$ & $105.03(15)$ & $\mathrm{P}(2)-\mathrm{Ru}(1)-\mathrm{Cl}(3)$ & $99.41(15)$ \\
$\mathrm{P}(2)-\mathrm{Ru}(1)-\mathrm{Cl}(4)$ & $176.32(16)$ & $\mathrm{Cl}(1)-\mathrm{Ru}(1)-\mathrm{Cl}(2)$ & $91.49(14)$ \\
$\mathrm{Cl}(1)-\mathrm{Ru}(1)-\mathrm{Cl}(3)$ & $171.44(14)$ & $\mathrm{Cl}(1)-\mathrm{Ru}(1)-\mathrm{Cl}(4)$ & $95.74(14)$ \\
$\mathrm{Cl}(2)-\mathrm{Ru}(1)-\mathrm{Cl}(3)$ & $80.78(14)$ & $\mathrm{Cl}(2)-\mathrm{Ru}(1)-\mathrm{Cl}(4)$ & $78.15(14)$ \\
$\mathrm{Cl}(3)-\mathrm{Ru}(1)-\mathrm{Cl}(4)$ & $79.15(14)$ & $\mathrm{P}(1)-\mathrm{C}(10)-\mathrm{P}(2)$ & $94.2(7)$ \\
$\mathrm{Ar}-\mathrm{Ru}(2)-\mathrm{Cl}(2)$ & $129.5(5)$ & $\mathrm{Ar}-\mathrm{Ru}(2)-\mathrm{Cl}(3)$ & $133.2(5)$ \\
$\mathrm{Ar}-\mathrm{Ru}(2)-\mathrm{Cl}(4)$ & $132.9(5)$ & $\mathrm{Cl}(2)-\mathrm{Ru}(2)-\mathrm{Cl}(3)$ & $80.96(14)$ \\
$\mathrm{Cl}(2)-\mathrm{Ru}(2)-\mathrm{Cl}(4)$ & $80.67(14)$ & $\mathrm{Cl}(3)-\mathrm{Ru}(2)-\mathrm{Cl}(4)$ & $79.27(14)$
\end{tabular}

${ }^{a} \mathrm{Ar}^{\dagger}$ represents the centroid of the $\eta^{6}-\mathrm{C}_{6}$ ring.

$\mathrm{CH}_{2} \mathrm{P}\left(\mathrm{C}_{6} \mathrm{~F}_{5}\right)_{2}$ via the cation $\left[\mathrm{Cp} * \mathrm{RhCl}\left\{\kappa P, \kappa P-\left(\mathrm{C}_{6} \mathrm{~F}_{5}\right)_{2} \mathrm{PCH}_{2}-\right.\right.$ $\left.\left.\mathrm{CH}_{2} \mathrm{P}\left(\mathrm{C}_{6} \mathrm{~F}_{5}\right)_{2}\right\}\right]^{+},{ }^{48}$ it is reasonable to presume that the thermolysis reaction between $[\mathrm{Cp} * \mathrm{RhCl}(\mu-\mathrm{Cl})]_{2}$ and 2 proceeds via $[\mathrm{Cp} * \mathrm{RhCl}(\kappa P, \kappa P-2)]^{+}$, the cation of $\mathbf{5}$. In order to test this hypothesis, $\mathbf{5}$ was treated with bis(1,8-dimethylamino)naphthalene (Proton Sponge). NMR spectroscopy indicated that $\mathbf{2}$ was formed in low yield, along with other, unidentified, rhodiumand phosphine-containing compounds. A maximum yield of $50 \%$ is expected from the $1: 1$ chloride:rhodium ratio of $\mathbf{5}$. Attempts to increase the yield by adding chloride were unsuccessful. However the observations give credence to the intermediacy of the cation of $\mathbf{5}$ in the thermolysis reaction between $[\mathrm{Cp} * \mathrm{RhCl}(\mu-\mathrm{Cl})]_{2}$ and $\mathbf{2}$ and allow us to propose a "clip on, flip off" reaction scheme (Scheme 4). The first steps involve coordination of 2 to give $[\mathrm{Cp} * \mathrm{RhCl}(\kappa P, \kappa P-2)]^{+}$, presumably as the chloride salt. This undergoes dehydrofluorinative carboncarbon coupling, which tethers the $\eta^{5}$-cyclopentadienyl ligand to one phosphine moiety. The geometry change associated with this process, in particular the large reductions in $\mathrm{Cp}^{\dagger}-\mathrm{Rh}-\mathrm{P}$ angle and $\mathrm{Rh}-\mathrm{P}$ bond distance, so increase the strain within the cation that the untethered phosphine moiety is forced to dissociate, releasing the strain in the $\mathrm{P}-\mathrm{C}-\mathrm{P}$ angle. In further support of this scheme attempts to enforce $\eta^{5}, \kappa P, \kappa P$ coordination of the ligand by treatment of $\mathbf{9}$ with sodium tetrafluoroborate or sodium hexafluoroantimonate were unsuccessful.

The reaction between $[\mathrm{Cp} * \operatorname{IrCl}(\mu-\mathrm{Cl})]_{2}$ and 2 equiv of 2 in refluxing benzene afforded a mixture comprising predominantly $\left[\left\{\eta^{5}, \kappa P-\mathrm{C}_{5} \mathrm{Me}_{4} \mathrm{CH}_{2} \mathrm{C}_{6} \mathrm{~F}_{4}-2-\mathrm{P}\left(\mathrm{C}_{6} \mathrm{~F}_{5}\right) \mathrm{CH}_{2} \mathrm{P}\left(\mathrm{C}_{6} \mathrm{~F}_{5}\right)_{2}\right\} \mathrm{IrCl}_{2}\right]$, 10. Unfortunately all attempts to isolate $\mathbf{1 0}$ were unsuccessful. The

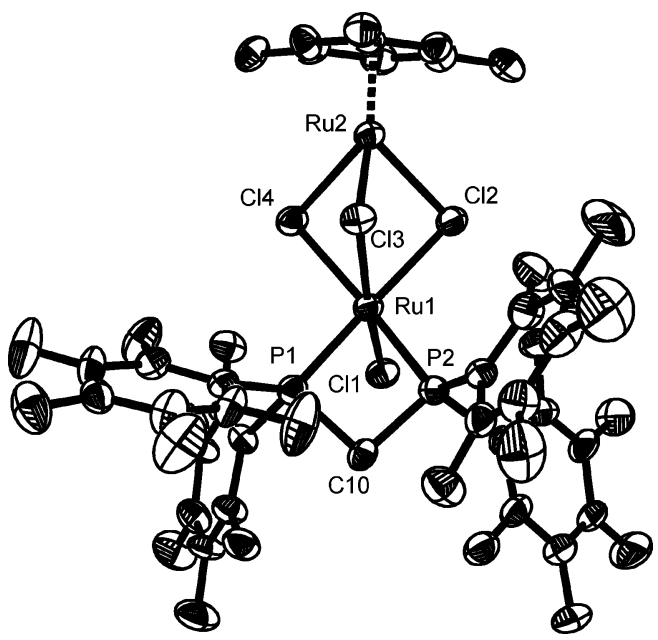

Figure 6. Structure of $\left[\left(\eta^{6}-\right.\right.$ mesitylene $) \mathrm{Ru}(\mu-\mathrm{Cl})_{3} \mathrm{RuCl}\{\kappa P, \kappa P-$ $\left.\left.\left(\mathrm{C}_{6} \mathrm{~F}_{5}\right)_{2} \mathrm{PCH}_{2} \mathrm{P}\left(\mathrm{C}_{6} \mathrm{~F}_{5}\right)_{2}\right\}\right], 11$. Thermal ellipsoids are at the $30 \%$ level. Hydrogen atoms are omitted for clarity.

Table 4. Transfer Hydrogenation ${ }^{a}$ of Acetophenone Catalyzed by Ruthenium Complexes

\begin{tabular}{|c|c|c|}
\hline entry & catalyst & $\begin{array}{l}\text { percentage } \\
\text { conversion }\end{array}$ \\
\hline 1 & $1 / 2\left[\left(\eta^{6} \text {-toluene }\right) \mathrm{RuCl}(\mu-\mathrm{Cl})\right]_{2}$ & 24 \\
\hline 2 & $1 / 2\left[\left(\eta^{6} \text {-mesitylene }\right) \operatorname{RuCl}(\mu-\mathrm{Cl})\right]_{2}$ & 57 \\
\hline 3 & $1 / 2\left[\left(\eta^{6}-p \text {-cymene }\right) \operatorname{RuCl}(\mu-\mathrm{Cl})\right]_{2}$ & 65 \\
\hline 4 & $1 / 2\left[\left(\eta^{6} \text {-mesitylene }\right) \mathrm{RuCl}(u-\mathrm{Cl})\right]_{2}+\mathrm{DPEN}$ & 90 \\
\hline 5 & $1 / 2\left[\left(\eta^{6}-p \text {-cymene }\right) \operatorname{RuCl}(\mu-\mathrm{Cl})\right]_{2}+\mathrm{DPEN}$ & 68 \\
\hline 6 & {$\left[\left(\eta^{6}\right.\right.$-mesitylene $\left.) \mathrm{RuCl}(\mathrm{dppe})\right] \mathrm{BF}_{4}$} & 77 \\
\hline 7 & {$\left[\left(\eta^{6}\right.\right.$-mesitylene $\left.) \operatorname{RuCl}(\mathbf{2})\right] \mathrm{BF}_{4}, \mathbf{8}$} & 21 \\
\hline 8 & $1 / 2\left[\left(\eta^{6}\right.\right.$-mesitylene $\left.) \mathrm{Ru}_{2}(\mathbf{2}) \mathrm{Cl}(\mu-\mathrm{Cl})_{3}\right], \mathbf{1 1}$ & 67 \\
\hline 9 & {$\left[\left(\eta^{6}-p\right.\right.$-cymene $\left.) \mathrm{RuCl}(2)\right] \mathrm{BF}_{4}, 7$} & 85 \\
\hline
\end{tabular}

${ }^{a}$ All reactions were conducted in propan-2-ol, [catalyst] $=2 \mathrm{mM}$, [acetophenone] $=0.2 \mathrm{M}, T=75{ }^{\circ} \mathrm{C},[\mathrm{KOH}]=2.5 \mathrm{mM}$, reaction time $2 \mathrm{~h}$; percentage conversions are the average of three experiments.

identity of $\mathbf{1 0}$ was confirmed by high-resolution mass spectrometry and its ${ }^{1} \mathrm{H},{ }^{19} \mathrm{~F}$, and ${ }^{31} \mathrm{P}\left\{{ }^{1} \mathrm{H}\right\}$ NMR spectra, which show features similar to 9. In particular, the ${ }^{31} \mathrm{P}\left\{{ }^{1} \mathrm{H}\right\}$ NMR exhibits a doublet resonance at $\delta_{\mathrm{P}} 11.0$ and a doublet of quintets resonance at $\delta_{\mathrm{P}}-69.2$ with a mutual coupling of $181 \mathrm{~Hz}$, and the ${ }^{1} \mathrm{H}$ NMR spectrum displays resonances at $\delta 3.93$ and 3.77 with a mutual coupling of $18.7 \mathrm{~Hz}$ characteristic of a methylene group linking an $\eta^{5}$-cyclopentadienyl ligand to $\mathrm{C}_{6} \mathrm{~F}_{4}$, in addition to four methyl resonances, three of which show coupling to one phosphorus atom.

The reaction between $\left[\left(\eta^{6} \text {-mesitylene }\right) \mathrm{RuCl}(\mu-\mathrm{Cl})\right]_{2}$ and 2 equiv of $\mathbf{2}$ in refluxing methanol/dichloromethane yielded [ $\left(\eta^{6}-\right.$ mesitylene $\left.) \mathrm{Ru}(\mu-\mathrm{Cl})_{3} \mathrm{RuCl}(\kappa P, \kappa P-2)\right]$ (11) in $96 \%$ yield with respect to ruthenium. The identity of $\mathbf{1 1}$ was elucidated by single-crystal X-ray diffraction (Figure 6), with which the analytical and NMR spectroscopic data are entirely consistent. Complexes of this type have been reported previously, but their syntheses involved reaction of an $\eta^{6}$-arene ruthenium complex and a ruthenium diphosphine complex rather than displacement of an $\eta^{6}$-arene ligand. ${ }^{51,52}$ Selected bond distances and angles are given in Table 3. The structure possesses approximate octahedral geometry about $\mathrm{Ru}(1)$ and three-legged piano stool geometry about $\mathrm{Ru}(2)$ and is similar to those of $\left[\left(\eta^{6}-\mathrm{C}_{6} \mathrm{H}_{4} \mathrm{RR}^{\prime}-\right.\right.$ $\left.1,4) \mathrm{Ru}(\mu-\mathrm{Cl})_{3} \mathrm{RuCl}\left(\kappa P, \kappa P-\mathrm{Ph}_{2} \mathrm{P}\left(\mathrm{CH}_{2}\right)_{4} \mathrm{PPh}_{2}\right)\right]\left(\mathrm{R}=\mathrm{R}^{\prime}=\mathrm{H} ;{ }^{51}\right.$ $\left.\mathrm{R}=\mathrm{Me}, \mathrm{R}^{\prime}=\mathrm{CHMe}_{2}{ }^{52}\right)$. The terminal $\mathrm{Ru}-\mathrm{Cl}$ distances are

(51) de Araujo, M. P.; Valle, E. M. A.; Ellena, J.; Castellano, E. E.; dos Santos, E. N.; Batista, A. A. Polyhedron 2004, 23, 3163.

(52) da Silva, A. C.; Piotrowski, H.; Mayer, P.; Polborn, K.; Severin, K. Eur. J. Inorg. Chem. 2001, 685. 
Table 5. Liquid Sampling of Transfer Hydrogenation ${ }^{a}$ of Acetophenone Catalyzed by Ruthenium Complexes

\begin{tabular}{cccccc}
\hline & \multicolumn{5}{c}{ percentage conversion } \\
\cline { 2 - 6 } catalyst & $10 \mathrm{~min}$ & $20 \mathrm{~min}$ & $30 \mathrm{~min}$ & $1 \mathrm{~h}$ & $1.5 \mathrm{~h}$ \\
\hline $1 / 2\left[\left(\eta^{6} \text {-mesitylene }\right) \mathrm{RuCl}(\mu-\mathrm{Cl})\right]_{2}+\mathrm{DPEN}$ & 23 & 44 & 48 & 89 & $2 \mathrm{~h}$ \\
{$\left[\left(\eta^{6}-p\right.\right.$-cymene $\left.) \mathrm{RuCl}(2)\right] \mathrm{BF}{ }_{4}, 7$} & 47 & 50 & 69 & 71 & 76 \\
${ }^{a}$ All reactions were conducted in propan-2-ol, [catalyst] $=2 \mathrm{mM},\left[\right.$ acetophenone] $=0.2 \mathrm{M}, T=75{ }^{\circ} \mathrm{C},[\mathrm{KOH}]=2.5 \mathrm{mM}$.
\end{tabular}

Table 6. Transfer Hydrogenation ${ }^{a}$ of Acetophenone Catalyzed by Rhodium Complexes

\begin{tabular}{|c|c|c|}
\hline entry & catalyst & $\begin{array}{l}\text { percentage } \\
\text { conversion }\end{array}$ \\
\hline 1 & $1 / 2\left[\left(\eta^{5}-\mathrm{C}_{5} \mathrm{Me}_{4} \mathrm{H}\right) \mathrm{RhCl}(u-\mathrm{Cl})\right]_{2}$ & 35 \\
\hline 2 & $1 / 2[\mathrm{Cp} * \mathrm{RhCl}(\mu-\mathrm{Cl})]_{2}$ & 80 \\
\hline 3 & $1 / 2[\mathrm{Cp} * \mathrm{RhCl}(\mu-\mathrm{Cl})]_{2}+\mathrm{DPEN}$ & 90 \\
\hline 4 & $1 / 2[\mathrm{Cp} * \mathrm{RhCl}(\mu-\mathrm{Cl})]_{2}+(\mathrm{S})$-phenylglycinol & 63 \\
\hline 5 & $\mathrm{Cp} * \mathrm{RhCl}_{2}\left(\mathrm{PPh}_{3}\right)$ & 68 \\
\hline 6 & {$\left[\left(\eta^{5}-\mathrm{C}_{5} \mathrm{Me}_{4} \mathrm{H}\right) \mathrm{RhCl}(\mathrm{dppe})\right] \mathrm{BF}_{4}$} & 37 \\
\hline 7 & {$[\mathrm{Cp} * \mathrm{RhCl}(\mathrm{dppm})] \mathrm{BF}_{4}$} & 50 \\
\hline 8 & {$[\mathrm{Cp} * \mathrm{RhCl}(\mathrm{dfppe})] \mathrm{BF}_{4}$} & 29 \\
\hline 9 & {$[\mathrm{Cp} * \mathrm{RhCl}(\mathbf{2})] \mathrm{BF}_{4}, \mathbf{5}$} & 49 \\
\hline 10 & 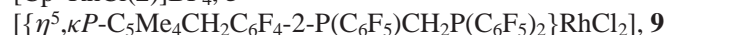 & 81 \\
\hline 11 & {$\left[\left(\eta^{5}, \kappa P, \kappa P-\mathrm{C}_{5} \mathrm{Me}_{4} \mathrm{CH}_{2}-2-\mathrm{C}_{5} \mathrm{~F}_{3} \mathrm{~N}-4-\mathrm{PPhCH}_{2} \mathrm{CH}_{2} \mathrm{PPh}_{2}\right) \mathrm{RhCl} \mathrm{BF}_{4}, \mathbf{1}\right.$} & 94 \\
\hline
\end{tabular}

${ }^{a}$ All reactions were conducted in propan-2-ol, [catalyst] $=2 \mathrm{mM}$, [acetophenone] $=0.2 \mathrm{M}, T=75{ }^{\circ} \mathrm{C},[\mathrm{KOH}]=2.5 \mathrm{mM}$, reaction time $2 \mathrm{~h}$; percentage conversions are the average of three experiments.

Table 7. Liquid Sampling of Transfer Hydrogenation ${ }^{a}$ of Acetophenone Catalyzed by Rhodium Complexes

\begin{tabular}{|c|c|c|c|c|c|c|}
\hline \multirow[b]{2}{*}{ catalyst } & \multicolumn{6}{|c|}{ percentage conversion } \\
\hline & $10 \mathrm{~min}$ & $20 \mathrm{~min}$ & $30 \mathrm{~min}$ & $1 \mathrm{~h}$ & $1.5 \mathrm{~h}$ & $2 \mathrm{~h}$ \\
\hline$\left[\left(\eta^{5}, \kappa P, \kappa P-\mathrm{C}_{5} \mathrm{Me}_{4} \mathrm{CH}_{2}-2-\mathrm{C}_{5} \mathrm{~F}_{3} \mathrm{~N}-4-\mathrm{PPhCH}_{2} \mathrm{CH}_{2} \mathrm{PPh}_{2}\right) \mathrm{RhCl}\right], \mathbf{1}$ & 60 & 92 & 94 & 98 & & 98 \\
\hline
\end{tabular}

Table 8. Transfer Hydrogenation ${ }^{a}$ of Acetophenone Catalyzed by Iridium Complexes

\begin{tabular}{clc}
\hline entry & \multicolumn{1}{c}{ catalyst } & $\begin{array}{c}\text { percentage } \\
\text { conversion }\end{array}$ \\
\hline 1 & $1 / 2[\mathrm{Cp} * \operatorname{IrCl}(\mu-\mathrm{Cl})]_{2}$ & 40 \\
2 & $1 / 2[\mathrm{Cp} * \operatorname{IrCl}(2)] \mathrm{BF}_{4}, \mathbf{6}$ & 5 \\
3 & $1 / 2[\mathrm{Cp} * \operatorname{IrCl}(\mathrm{dfppe})] \mathrm{BF}_{4}$ & 1
\end{tabular}

${ }^{a}$ All reactions were conducted in propan-2-ol, [catalyst] $=2 \mathrm{mM}$, [acetophenone] $=0.2 \mathrm{M}, T=75^{\circ} \mathrm{C},[\mathrm{KOH}]=2.5 \mathrm{mM}$, reaction time $2 \mathrm{~h}$; percentage conversions are the average of three experiments; dfppe $=$ $\left(\mathrm{C}_{6} \mathrm{~F}_{5}\right)_{2} \mathrm{PCH}_{2} \mathrm{CH}_{2} \mathrm{P}\left(\mathrm{C}_{6} \mathrm{~F}_{5}\right)_{2}$.

identical within $3 \sigma$ for the three complexes (2.384(4) $\AA$ ), and the distances of the bridging $\mathrm{Ru}-\mathrm{Cl}$ bond trans to chloride are similar $(2.407(2)$ to $2.4343(8) \AA$ ), but the distances of the bridging $\mathrm{Ru}-\mathrm{Cl}$ bond trans to phosphorus range from 2.472(4) to 2.5960 (8) $\AA$. The $\mathrm{Ru}-\mathrm{P}$ distances of $\mathbf{1 1}$ are shorter than those of $\mathbf{8}$, and consequently the $\mathrm{P}-\mathrm{Ru}-\mathrm{P}$ angle is slightly larger.

The ${ }^{19} \mathrm{~F}$ NMR spectrum indicates hindered rotation about one pair of $\mathrm{P}-\mathrm{C}_{6} \mathrm{~F}_{5}$ bonds. A minimum value of $\Delta G^{\ddagger}$ of $61 \mathrm{~kJ} \mathrm{~mol}^{-1}$ was calculated ${ }^{47}$ from variable-temperature ${ }^{19} \mathrm{~F}$ NMR spectra. The spectra did not allow calculation of $\Delta G^{\ddagger}$ for rotation about the other pair of $\mathrm{P}-\mathrm{C}_{6} \mathrm{~F}_{5}$ bonds.

Comparison of Catalytic Activity. Catalyst testing was conducted to assess the effects of coordinating chelating phosphine ligands on the ability of piano stool complexes to catalyze hydrogen transfer. Of particular interest was the comparison between a phenyl and fluorinated phenyl functionality and the effects of tethering the phosphine and capping group to make a highly chelating pocket. The reaction chosen for comparison was the hydrogen transfer from propan-2-ol to acetophenenone, as this is the substrate most commonly reported in the literature (Scheme 1). Conditions chosen are consistent with those reported in industrial patents for the operation of catalysts for the reduction of alkyl aryl ketones and the racemization (as part of a dynamic kinetic resolution) of secondary alcohols, respectively. ${ }^{19,29}$ A relatively low substrate concentration and reaction time were chosen in order to minimize the back-reaction and thus give comparable results; higher turnover frequencies are achievable using higher substrate concentrations. Reproducibility was found to vary with the temperature of the reaction; higher temperatures gave more reproducible results.

Ruthenium Catalysts. The percentage conversions of acetophenone to $\mathrm{rac}$-phenylethanol for a range of aryl ruthenium catalysts tested under identical conditions are given in Table 4. The increased conversion for the mesitylene and cymene rings (entries 2 and 3) compared with the toluene derivative (entry 1) indicates that under these conditions increased electron density on the metal increases the rate of hydrogen transfer. This is consistent with the improvements observed when the $\sigma$-donor DPEN is added (entries 4 and 5). When the amine is substituted for bis(diphenylphosphino)ethane (dppe, entry 6), rate enhancement is again observed, but this is lesser, perhaps due to the ability of the amine to react by the metal-ligand bifunctional mechanism. The behavior of the dfppm (2) complexes $(\mathbf{8}, \mathbf{1 1}$, and $\mathbf{7}$, entries 7-9) is difficult to predict, as 2 varies from a poison (in complex 8, entry 7) to a good promoter (in complex 7, entry 9). The reduction in reaction rate when $\mathbf{2}$ and mesitylene are coordinated may be due to steric bulk, as the spatial distribution of substituents around the metal site is more even on mesitylene than cymene. The activity of $\mathbf{7}$ is remarkable for a catalyst with no Brønsted basic ligand site and was deemed worthy of further study.

The best two catalysts, $1 / 2\left[\left(\eta^{6} \text {-mesitylene }\right) \operatorname{RuCl}(\mu-\mathrm{Cl})\right]_{2}+$ DPEN and 7, were sampled after various times in order to better measure the rate of catalysis. The results are presented in Table 5. Under these conditions we found that phosphine-substituted catalyst 7 (turnover frequency, TOF, based on measurement after $10 \mathrm{~min}, 282 \mathrm{~h}^{-1}$ ) was twice as active as the amine-promoted 
Chart 1. Conversion of Acetophenone as a Function of Time

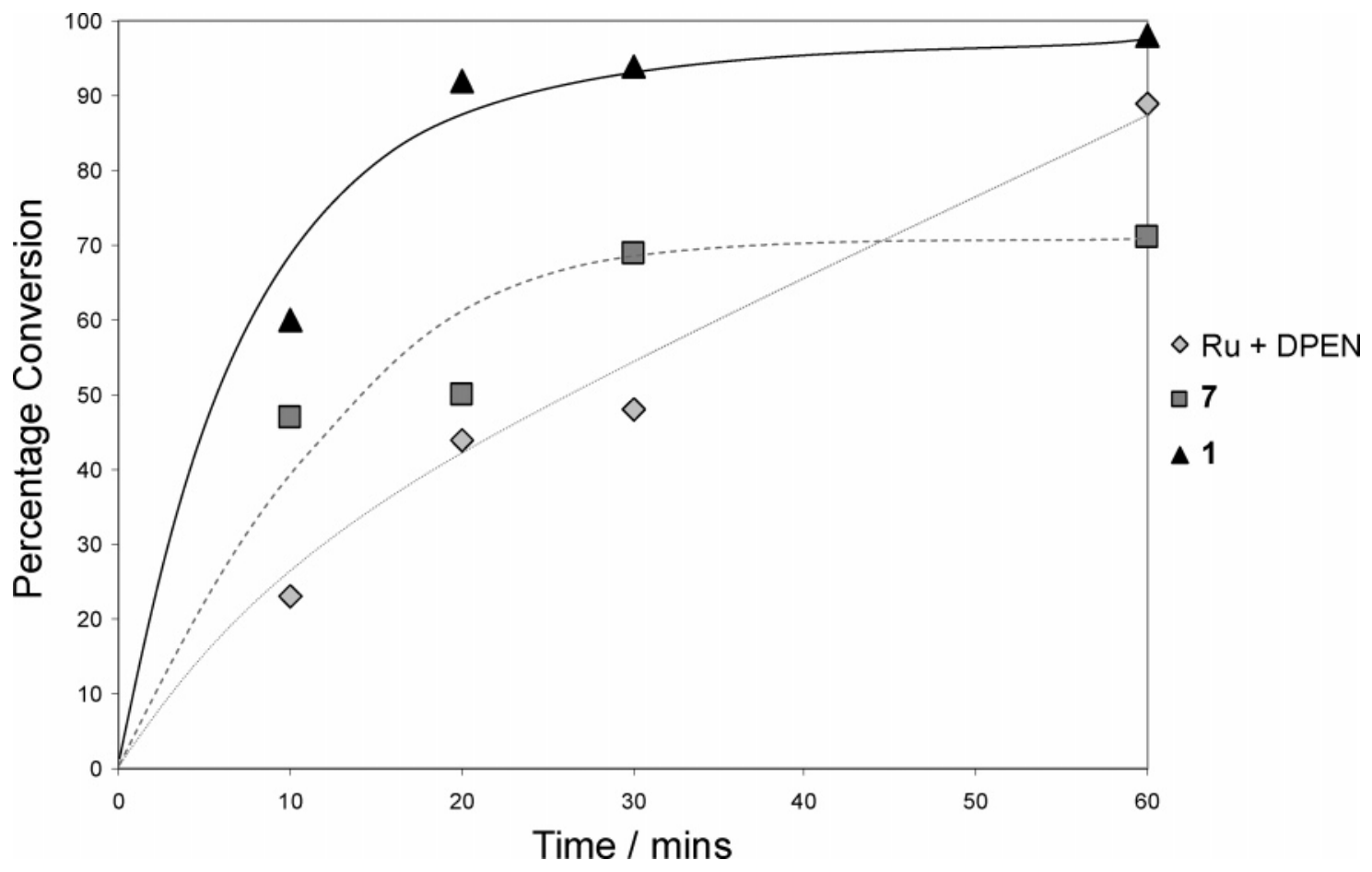

catalyst precursor $1 / 2\left[\left(\eta^{6} \text {-mesitylene }\right) \operatorname{RuCl}(\mu-\mathrm{Cl})\right]_{2}+\mathrm{DPEN}$ (TOF based on measurement after $10 \mathrm{~min}, 138 \mathrm{~h}^{-1}$ ).

Rhodium Catalysts. The results of hydrogenation of acetophenone catalyzed by rhodium complexes are given in Table 6 . The comparison of tetramethyl and pentamethyl cyclopentadienyl derivatives (entries 1 and 2) would suggest that increasing the electron density can increase the rate of transfer hydrogenation, and consistent with this is the slight increase in conversion achieved for the tetramethyl cyclopentadienyl complex on coordinating dppe (entry 6). There was also an increased conversion on the addition of DPEN to pentamethylcyclopentadienyl rhodium (entry 3), but this must be attributed to the metal-ligand bifuntional mechanism (Scheme 2), as all other bidentate modifiers added were found to decrease the conversion of acetophenone in $2 \mathrm{~h}$ (entries 4, 7, 8, and 9) relative to the parent chloride (entry 2). The poisoning effect of the phosphine ligands tested is reversed by tethering the phosphine and cyclopentadienyl functionality together (either as a $\mathrm{Cp}-\mathrm{P}$ or $\mathrm{Cp}-\mathrm{PP}$ complex), as illustrated by entries 10 and 11. Complex 9 had hydrogen transfer activity similar to $[\mathrm{Cp} * \mathrm{RhCl}(\mu-\mathrm{Cl})]_{2}$, whereas 1 was the most active hydrogen transfer catalyst tested.

The excellent activity of $\mathbf{1}$ warranted further study. The hydrogen transfer activity as a function of time is presented in Table 7. The TOF of the catalyst, based on the $10 \mathrm{~min}$ measurement, was $360 \mathrm{~h}^{-1}$.

Iridium Catalysts. The activity of iridium-based catalysts was found to be comparatively low under these conditions (Table 8).

Summary of Results from the Initial Catalyst Tests. Ruthenium catalysts exhibited a slightly lower inherent rate of hydrogen transfer and benefited from the coordination of good donor chelating ligands; the "capping" aryl group and bidentate ligand must be matched to prevent steric overcrowding and maximize rates. The rhodium catalysts benefited from a pentamethyl cyclopentadienyl group as a capping ligand, and the electron donation from this ligand makes the attachment of bidentate donor ligands unnecessary. A reduction in rate was observed for chelating phosphine ligands attached to the metal center unless the phosphine was tethered to the cyclopentadienyl, at which point the activity of the catalyst increased significantly. The iridium phosphine complexes tested were very poor catalysts.

A graph of the conversion of acetophenone as a function of time for the excellent catalysts $1 / 2\left[\left(\eta^{6} \text {-mesitylene }\right) \mathrm{RuCl}(\mu-\mathrm{Cl})\right]_{2}$ + DPEN, $\mathbf{1}$, and $\mathbf{7}$ is given (Chart 1). $\mathbf{1}$ outperforms the other catalysts and shows a profile consistent with a high turnover that becomes rate limited at lower substrate concentrations. Amine-promoted ruthenium performs as expected for a slower catalyst. The profile of 7 reveals that this reaction slowed considerably long before full conversion was achieved. This is a result of either a catalyst that is poor at low substrate concentrations or one that slowly decomposes under the reaction conditions. In order to test the stability of piano stool complexes of chelating phosphines under hydrogen transfer conditions, in situ NMR studies were conducted.

In Situ NMR Studies. In order to verify that the active catalysts contained phosphine-bound species and try to determine the resting state of the catalyst, selected catalysts were analyzed by ${ }^{31} \mathrm{P}$ NMR during catalytic activity.

In Situ NMR of a Ruthenium Catalyst. [( $\eta^{6}$-mesitylene)$\mathrm{RuCl}(\kappa P, \kappa P$-dppe $)] \mathrm{BF}_{4}$ dissolved in propan-2-ol at $343 \mathrm{~K}$ exhibited one resonance at $\delta_{\mathrm{P}} 71.8$ in the ${ }^{31} \mathrm{P}\left\{{ }^{1} \mathrm{H}\right\}$ NMR spectrum. The addition of potassium hydroxide led to the disappearance of this signal and the appearance of resonances at $\delta_{\mathrm{P}} 82.7$ and 35.4 (Figure 7). The addition of acetophenone did not change the spectrum. During catalytic activity a further resonance at $\delta_{\mathrm{P}} 83.2$ grew in. The resting state appeared to resonate at $\delta_{\mathrm{P}} 35.4$, as this signal increased in intensity relative to the other resonances throughout. After $2 \mathrm{~h}$ the solution was cooled, and the room-temperature spectrum consisted of a major resonance at $\delta_{\mathrm{P}}$ 82.7, a lesser resonance at $\delta_{\mathrm{P}} 35.4$, and a resonance at $\delta_{\mathrm{P}} 64.2$ of low intensity. Removal of the solvent and addition of chloroform led to the complete regeneration of the initial spectrum $\left(\delta_{\mathrm{P}} 71.8\right)$, revealing the catalyst to be intact.

In the presence of propan-2-ol and deuterium-labeled propan2-ol $\left(d_{8}\right)$ a strong broad signal was observed at $\delta_{\mathrm{P}} 82.1$ in 


\section{$82.7 \mathrm{ppm}$}

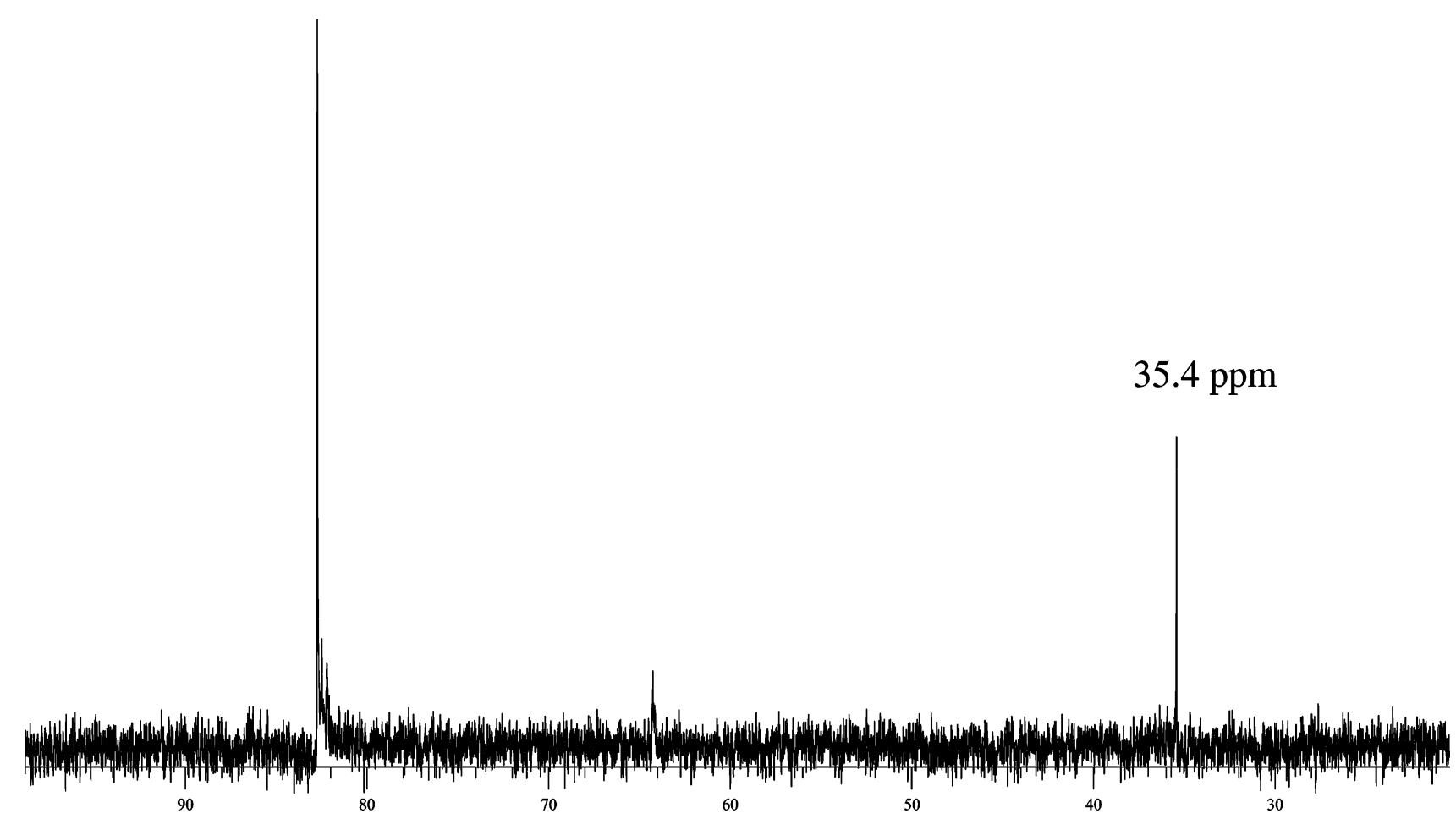

Figure 7. ${ }^{31} \mathrm{P}$ spectrum resulting from exposing $\left[\left(\eta^{6}\right.\right.$-mesitylene $) \mathrm{RuCl}(\kappa P, \kappa P$-dppe $\left.)\right] \mathrm{BF}_{4}$ to hydrogen transfer conditions.

addition to the $\delta_{\mathrm{P}} 82.7$ resonance, whereas the resonances observed at $\delta_{\mathrm{P}} 35.4$ in pure propan-2-ol were absent. We therefore suggest that $\left[\left(\eta^{6} \text {-mesitylene }\right) \mathrm{Ru}(\mathrm{H})(\kappa P, \kappa P \text {-dppe })\right]^{+}$and its deuterium analogue resonate at $\delta_{\mathrm{P}} 82-83$, and these species have a close association with the organic reactants, leading to differences in chemical shift for $\left[\left(\eta^{6}\right.\right.$-mesitylene $) \mathrm{Ru}(\mathrm{H})(\kappa P, \kappa P$ dppe $)] \mathrm{OC}_{3} \mathrm{H}_{6}\left(\delta_{\mathrm{P}} 82.7\right)$ and $\left[\left(\eta^{6}\right.\right.$-mesitylene $) \mathrm{Ru}(\mathrm{H})(\kappa P, \kappa P$-dppe $\left.)\right]-$ $\mathrm{OC}_{8} \mathrm{H}_{8}\left(\delta_{\mathrm{P}}\right.$ 83.2). When the proton-decoupled spectrum was recorded and rapidly followed by a proton-coupled spectrum, the resonance at $\delta 82.7$ collapsed in intensity. The resulting resonance is believed to be a doublet of multiplets, $J_{\mathrm{PH}}=38$ $\mathrm{Hz}$, consistent with a hydride complex. ${ }^{53,54}$

Substitution of propan-2-ol by propan-1-ol led to the formation of a resonance at $\delta_{\mathrm{P}} 49.2$ but no resonance at $\delta_{\mathrm{P}} 35.4$. On addition of potassium hydroxide, the intensity of this resonance increased as the reaction proceeded, behaving similarly to the resonance at $\delta 35.4$ observed in propan-2-ol. We therefore assign the resonance at $\delta_{\mathrm{P}} 49.2$ to $\left[\left(\eta^{6}\right.\right.$-mesitylene $) \mathrm{Ru}\left(\mathrm{OCH}_{2} \mathrm{CH}_{2} \mathrm{CH}_{3}\right)$ $(\kappa P, \kappa P$-dppe $)]^{+}$and that at $\delta_{\mathrm{P}} 35.4$ to $\left[\left(\eta^{6}\right.\right.$-mesitylene $) \mathrm{Ru}\{\mathrm{OCH}-$ $\left.\left(\mathrm{CH}_{3}\right)_{2}\right\}(\kappa P, \kappa P$-dppe $\left.)\right]^{+}$.

Attempts to isolate and characterize a prop-2-oxide derivative failed. The presence of a large quantity of a prop-2-oxide complex in solution during catalysis would suggest that the rate could be increased by shifting the $\beta$ - $\mathrm{H}$ transfer equilibrium toward the hydride (Scheme 5). The formation of a crowded transition state for this reaction may explain why some combinations of capping group and bidentate ligand lead to low rates of hydrogen transfer.

In Situ NMR Spectroscopy of a Rhodium Catalyst. The ${ }^{31} \mathrm{P}$ NMR spectrum of salt $\mathbf{5}$ in propan-2-ol and acetophenone at $343 \mathrm{~K}$ exhibited a doublet at $\delta_{\mathrm{P}}-33.2$ with ${ }^{1} J_{\mathrm{RhP}}=130 \mathrm{~Hz}$.

(53) Harding, P. A.; Robinson, S. D.; Henrick, K. J. Chem. Soc., Dalton Trans. 1988, 415.

(54) (a) Guan, H.; Iimura, M.; Magee, M. P.; Norton, J. R.; Janak, K. E. Organometallics 2003, 22, 4084. (b) Josh, F. L.; Roundhill, D. M. Organometallics 1992, 11, 1749.
Scheme 5. Formation of the Ruthenium Hydride

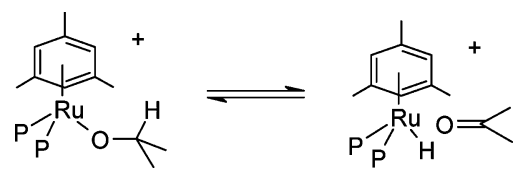

Potassium hydroxide was added to the reaction, and the resultant solution gave one doublet at $\delta_{\mathrm{P}}-66.1$ with ${ }^{1} J_{\mathrm{RhP}}=213 \mathrm{~Hz}$. These results indicate the phosphine remains chelated to rhodium during catalysis. The shift to lower frequency is similar to the shift that occurred in the $\left[\left(\eta^{6}\right.\right.$-mesitylene $\left.) \mathrm{RuCl}(\mathrm{dppe})\right] \mathrm{BF}_{4}$ experiment, and by analogy we assign the resonance at $\delta_{\mathrm{P}}-66.1$ to $\left[\mathrm{Cp} * \mathrm{Rh}\left\{\mathrm{OCH}\left(\mathrm{CH}_{3}\right)_{2}\right\}(\kappa P, \kappa P-2)\right]^{+}$.

Conclusions from in Situ NMR Experiments. In both cases (phosphine-modified $\mathrm{Ru}(\mathrm{II})$ and $\mathrm{Rh}(\mathrm{III})$ ) the spectrum resulting from the addition of potassium hydroxide in propan-2-ol contained a resonance shifted to lower frequency by $\delta_{\mathrm{P}} 33-$ 36. We assign this resonance to the primary product of the removal of chloride and association of prop-2-oxide. The addition of the substrate does not greatly affect the spectrum, and in the middle of catalytic activity the resonance at lower frequency dominates. We conclude that the mechanism, as depicted in Scheme 1, lies to the right-hand side with a ratelimiting insertion migration reaction as depicted (for $\mathrm{Ru}$ ) in Scheme 5. This explains why the addition of a Brønsted basic site and the initiation of a ligand-assisted pathway as depicted in Scheme 2 increase the rate of the reaction.

The low hydrogen transfer activity of the parent ruthenium dichloride complexes suggests that the removal of chloride is limiting the rate of reaction in the absence of phosphine donors. The addition of phosphine to Ru helps to stabilize the primary product of chloride dissociation and therefore increase the rate. This is not the case for pentamethylcyclopentadienyl rhodium catalysts, and they show a high rate of reaction without promoters. 
Table 9. Transfer Hydrogenation ${ }^{a}$ of Acetophenone at Higher Substrate Concentration

\begin{tabular}{|c|c|c|c|}
\hline catalyst & conversion/\% & rate $/ \mathrm{mol} \mathrm{dm}^{-3} \mathrm{~h}^{-1}$ & $\mathrm{TOF} / \mathrm{h}^{-1}$ \\
\hline $\begin{array}{l}{\left[\left(\eta^{5}, \kappa P, \kappa P-\mathrm{C}_{5} \mathrm{Me}_{4} \mathrm{CH}_{2}-2-\mathrm{C}_{5} \mathrm{~F}_{3} \mathrm{~N}-4-\mathrm{PPhCH}_{2} \mathrm{CH}_{2} \mathrm{PPh}_{2}\right) \mathrm{RhCl}_{3} \mathrm{BF}_{4}, \mathbf{1}\right.} \\
{\left[\left(\eta^{6}-p \text {-cymene }\right) \mathrm{RuCl}(2)\right] \mathrm{BF}_{4}, \mathbf{7}} \\
{\left[\left(\eta^{6} \text {-mesitylene }\right) \mathrm{RuCl}(\mathrm{dppe})\right] \mathrm{BF}_{4}}\end{array}$ & $\begin{array}{l}65 \\
52 \\
13\end{array}$ & $\begin{array}{l}0.65 \\
0.52 \\
0.13\end{array}$ & $\begin{array}{r}325 \\
260 \\
65\end{array}$ \\
\hline
\end{tabular}

${ }^{a}$ All reactions were conducted in propan-2-ol, [catalyst] $=2 \mathrm{mM}$, [acetophenone] $=2 \mathrm{M}, T=75^{\circ} \mathrm{C},[\mathrm{KOH}]=2.5 \mathrm{mM}$, reaction time $2 \mathrm{~h}$.

Table 10. Oppenauer Oxidation ${ }^{a}$ of rac-Phenyl Alcohol

\begin{tabular}{lcr}
\hline \multicolumn{1}{c}{ catalyst } & conversion \% & TOF \\
\hline $1 / 2[\mathrm{Cp} * \mathrm{RhCl}(\mu-\mathrm{Cl})]_{2}$ & 57 & 29 \\
{$\left[\left(\eta^{5}, \kappa P, \kappa P-\mathrm{C}_{5} \mathrm{Me}_{4} \mathrm{CH}_{2}-2-\mathrm{C}_{5} \mathrm{~F}_{3} \mathrm{~N}-4-\mathrm{PPhCH}_{2} \mathrm{CH}_{2} \mathrm{PPh}_{2}\right) \mathrm{RhCl}_{\mathrm{B} F}, \mathbf{1}\right.$} & 48 & 24 \\
{$\left[\left(\eta^{6}-p-\mathrm{cymene}\right) \mathrm{RuCl}_{2}(\mathbf{2})\right] \mathrm{BF}_{4}, \mathbf{7}$} & 16 & 8 \\
$1 / 2[\mathrm{Cp} * \mathrm{IrCl}(\mu-\mathrm{Cl})]_{2}$ & 74 & 37
\end{tabular}

${ }^{a}$ All reactions were conducted in propan-2-one, [catalyst $]=2 \mathrm{mM},[$ rac-phenyl alcohol $]=0.2 \mathrm{mM}, T=57^{\circ} \mathrm{C},[\mathrm{KOH}]=2.5 \mathrm{mM}$, reaction time $2 \mathrm{~h}$.

The precise metal environment engineered by our highly chelating ligands stimulates desired reactivity but also protects the catalytic center from decomposition. The catalysts $\mathbf{9}$ and $\mathbf{1}$ with "tethered" ligands of $\mathrm{Cp}-\mathrm{P}$ and $\mathrm{Cp}-\mathrm{PP}$ functionalities promote hydrogen transfer relative to the parent chloride and bidentate phosphine complexes. We have successfully created a pocket for reactivity that stimulates hydrogen transfer.

Higher Substrate Concentrations. The commercial success of industrial reactions such as hydrogen transfer depends upon conversion of a certain quantity of substrate per unit time, and therefore we thought it relevant to test our catalysts at a higher substrate concentration. The conversions of acetophenone over 2 h using catalysts $\mathbf{1}, \mathbf{7}$, and $\left[\left(\eta^{6}\right.\right.$-mesitylene $) \operatorname{RuCl}(\kappa P, \kappa P$-dppe $\left.)\right]$ $\mathrm{BF}_{4}$ for 10 times higher substrate concentration are given in Table 9. Again the best catalyst was the tethered cyclopentadienyl phosphine rhodium(III) complex 1 , TOF $325 \mathrm{~h}^{-1}, 0.65$ mol dm ${ }^{-3} \mathrm{~h}^{-1}$.

Oxidizing Alcohols to Aldehydes. The synthesis of an aldehyde by catalytic oxidation (dehydrogenation) via hydrogen transfer to butanone or propan-2-one is termed Oppenauer oxidation. ${ }^{55}$ This reaction is of great interest to chemists attempting to prepare commodity chemicals from the side products of agriculture, as many of the molecules derived from natural sources are polyols. Reduction of these alcohols to carbonyls is useful, as ketones and aldehydes have rich and useful reaction chemistries. Recently derivatives of group 9 cyclopentadienyl complexes were found to be excellent catalysts for Oppenauer oxidation, opening up the possibility of simple oxidation of aliphatic alcohols in propan-2-one or butenone. ${ }^{56}$

We compared the activity of $\mathbf{1}, \mathbf{7},[\mathrm{Cp} * \mathrm{RhCl}(\mu-\mathrm{Cl})]_{2}$, and $\left[\mathrm{Cp}^{*} \operatorname{IrCl}(\mu-\mathrm{Cl})\right]_{2}$ as catalysts for the oxidation of rac-phenyl alcohol (Table 10).

Oppenauer oxidation employing $\mathrm{Ru}$ and $\mathrm{Rh}$ catalysts is slower in propan-2-one than hydrogenation of the ketone in propan2-ol, and this reflects the lower reaction temperature. $[\mathrm{Cp} * \mathrm{RhCl}-$ $(\mu-\mathrm{Cl})]_{2}, \mathbf{1}$, and particularly $[\mathrm{Cp} * \operatorname{IrCl}(\mu-\mathrm{Cl})]_{2}$ perform well, but the ruthenium catalyst $\mathbf{7}$ is comparatively poor at catalyzing this oxidation.

\section{Conclusion}

The pentafluorophenyl-substituted diphosphine $\left(\mathrm{C}_{6} \mathrm{~F}_{5}\right)_{2} \mathrm{PCH}_{2} \mathrm{P}-$ $\left(\mathrm{C}_{6} \mathrm{~F}_{5}\right)_{2}(2)$ is a versatile ligand that enabled the preparation of a range of piano stool complexes of $\mathrm{Ru}, \mathrm{Rh}$, and Ir. Piano stool complexes have been prepared and structurally characterized

(55) Oppenauer, R. V. Recl. Trav. Chem. Pays-Bas 1937, 56, 137.

(56) (a) Suzuki, T.; Morita, K.; Tsuchida, M.; Hiroi, K. J. Org. Chem. 2003, 68, 1601. (b) Hanasaka, F.; Fujita, K. I.; Yamaguchi, R. Organometallics 2006, 25, 826. with untethered and tethered $\eta^{5}, \kappa P, \kappa P$-cyclopentadienyl groups, and both classes of complex have shown promise as hydrogen transfer catalysts. In tests to compare piano stool rhodium complexes containing $\eta^{5}, \kappa P, \kappa P-\mathrm{Cp}-\mathrm{PP}, \eta^{5}, \kappa P-\mathrm{Cp}-\mathrm{P}$ and uncoupled $\mathrm{Cp}$ and diphosphine functionalities, the activity of the $\eta^{5}, \kappa P, \kappa P-\mathrm{Cp}-\mathrm{PP}$ complex 1 was unexpectedly high, and this result may enable the design of highly stable and enantioselective hydrogen transfer catalysts.

\section{Experimental Section}

General Considerations. The compounds bis(dichlorophosphino)methane (Strem) and bromopentafluorobenzene (Fluorochem) were used as supplied. The complexes $[\mathrm{Cp} * \mathrm{RhCl}(\mu-\mathrm{Cl})]_{2},{ }^{57}[\mathrm{Cp} * \mathrm{IrCl}-$ $(\mu-\mathrm{Cl})]_{2},{ }^{57}\left[\left(\eta^{6} \text {-cymene }\right) \mathrm{RuCl}(\mu-\mathrm{Cl})\right]_{2},{ }^{58}$ and $\mathbf{1}^{32}$ were prepared as described. The complex $\left[\left(\eta^{6} \text {-mesitylene }\right) \operatorname{RuCl}(\mu-\mathrm{Cl})\right]_{2}$ was prepared by heating $\left[\left(\eta^{6} \text {-cymene }\right) \operatorname{RuCl}(\mu-\mathrm{Cl})\right]_{2}$ in mesitylene as described for the preparation of tetra- and hexamethylbenzene complexes. ${ }^{59}$ The preparation of $\mathbf{2}$ was performed under dinitrogen using diethyl ether dried by distillation from sodium/benzophenone and stored over molecular sieves (4 ̊) under dinitrogen. No precautions to exclude air or moisture were taken for the other preparations.

${ }^{1} \mathrm{H},{ }^{19} \mathrm{~F}$, and ${ }^{31} \mathrm{P}$ NMR spectra were recorded at $25{ }^{\circ} \mathrm{C}$ using Bruker DPX300 or DRX500 spectrometers. ${ }^{1} \mathrm{H}$ NMR spectra (300.01 or $500.13 \mathrm{MHz}$ ) were referenced internally using the residual protio solvent resonance relative to $\mathrm{SiMe}_{4}(\delta 0),{ }^{19} \mathrm{~F}(282.26$ $\mathrm{MHz})$ externally to $\mathrm{CFCl}_{3}(\delta 0)$, and ${ }^{31} \mathrm{P}(121.45$ or $202.46 \mathrm{MHz})$ externally to $85 \% \mathrm{H}_{3} \mathrm{PO}_{4}(\delta 0)$. All chemical shifts are quoted in $\delta(\mathrm{ppm})$, using the high-frequency positive convention, and coupling constants in Hz. EI, LSIMS, and ES mass spectra were recorded on a VG Autospec X series mass spectrometer. Elemental analyses were carried out by ASEP, The School of Chemistry and Chemical Engineering, Queen's University Belfast.

$\left(\mathbf{C}_{6} \mathbf{F}_{5}\right)_{2} \mathbf{P C H} \mathbf{C H}_{\mathbf{2}} \mathbf{P}\left(\mathbf{C}_{\mathbf{6}} \mathbf{F}_{5}\right)_{\mathbf{2}}$ (2). Bis(dichlorophosphino)methane (0.6 $\mathrm{cm}^{3}, 4.6 \mathrm{mmol}$ ) was added by syringe to a solution of $\mathrm{C}_{6} \mathrm{~F}_{5} \mathrm{MgBr}$ in diethyl ether $\left(100 \mathrm{~cm}^{3}\right)$, freshly prepared from $\mathrm{C}_{6} \mathrm{~F}_{5} \mathrm{Br}(7 \mathrm{~g}, 0.27$ mol) and magnesium (0.56 g, $0.23 \mathrm{~mol})$. Heat was evolved, and a white precipitate was formed. The mixture was left at ambient temperature for $18 \mathrm{~h}$, then opened to the atmosphere. Water (30 $\left.\mathrm{cm}^{3}\right)$ and dichloromethane $\left(40 \mathrm{~cm}^{3}\right)$ were added and the organic layer was separated. The aqueous layer was extracted with dichloromethane $\left(3 \times 20 \mathrm{~cm}^{3}\right)$ and the combined organic solution dried over magnesium sulfate. The solution was filtered, concentrated by rotary evaporation, and filtered through $4 \mathrm{~cm}$ of neutral

(57) White, C.; Yates, A.; Maitlis, P. M. Inorg. Synth. 1992, 29, 228

(58) Bennett, M. A.; Smith, A. K. J. Chem. Soc., Dalton Trans. 1983, 1571

(59) Tocher, D. A.; Gould, R. O.; Stephenson, T. A.; Bennett, M. A.; Ennett, J. P.; Matheson, T. W.; Sawyer, L.; Shah, V. K. J. Chem. Soc., Dalton Trans. 1983, 1571. 
alumina $\left(6 \% \mathrm{H}_{2} \mathrm{O}\right)$. The alumina was washed with dichloromethane $\left(3 \times 10 \mathrm{~cm}^{3}\right)$. Removal of the solvent from the combined filtrate and washings by rotary evaporation afforded $\mathbf{2}$ as a white solid: $2.78 \mathrm{~g}(81.4 \%) .{ }^{1} \mathrm{H}$ NMR $\left(\mathrm{CDCl}_{3}\right): \delta 3.81\left(2 \mathrm{H}, \mathrm{t},{ }^{2} J_{\mathrm{PH}}=6.6 \mathrm{~Hz}\right)$. ${ }^{19} \mathrm{~F} \mathrm{NMR}\left(\mathrm{CDCl}_{3}\right): \delta-130.28\left(8 \mathrm{~F}, \mathrm{~m}, \mathrm{~F}_{\text {ortho }}\right),-147.81\left(4 \mathrm{~F}, \mathrm{t},{ }^{2} J_{\mathrm{FF}}\right.$ $\left.=20.9 \mathrm{~Hz}, \mathrm{~F}_{\text {para }}\right),-159.77\left(8 \mathrm{~F}, \mathrm{~m}, \mathrm{~F}_{\text {meta }}\right) .{ }^{31} \mathrm{P}\left\{{ }^{1} \mathrm{H}\right\} \mathrm{NMR}\left(\mathrm{CDCl}_{3}\right)$ : $\delta-52.1$ (second-order pattern of $\left[\mathrm{A}\left[\mathrm{X}_{4}\right]\left[\mathrm{Y}_{4}\right]\left[\mathrm{Z}_{2}\right]_{2}\right]_{2}$ spin system). LSIMS, $m / z$ (rel int): $744\left(23 \%, \mathrm{M}^{+}\right), 577\left(100 \%,\left[\mathrm{M}-\mathrm{C}_{6} \mathrm{~F}_{5}\right]^{+}\right)$. HRLSIMS: calcd for $\mathrm{C}_{25} \mathrm{H}_{2} \mathrm{~F}_{20} \mathrm{P}_{2}, 743.9313$; found $\mathrm{M}^{+}, 743.9323$. Anal. Calcd for $\mathrm{C}_{25} \mathrm{H}_{2} \mathrm{~F}_{20} \mathrm{P}_{2}$ : C, 40.32; $\mathrm{H}, 0.27$. Found: C, 40.05; $\mathrm{H}, 0.43$.

$\left(\mathrm{C}_{6} \mathrm{~F}_{5}\right)_{2} \mathbf{P C H} \mathrm{H}_{2} \mathrm{P}(\mathrm{O})\left(\mathrm{C}_{6} \mathrm{~F}_{5}\right)_{2}(3)$ and $\left(\mathrm{C}_{6} \mathrm{~F}_{5}\right)_{2} \mathrm{P}(\mathrm{O}) \mathrm{CH}_{2} \mathrm{P}(\mathrm{O})\left(\mathrm{C}_{6} \mathrm{~F}_{5}\right)_{2}$ (4). Aliquots of aqueous hydrogen peroxide were added to a sample of $\mathbf{2}$ in $\mathrm{CDCl}_{3}$. The formation of $\mathbf{3}$ and $\mathbf{4}$ was monitored by ${ }^{19} \mathrm{~F}$ and ${ }^{31} \mathrm{P}\left\{{ }^{1} \mathrm{H}\right\}$ NMR spectroscopy. Removal of the solvents by rotary evaporation gave a sample of $\mathbf{4}$, which was characterized by mass spectrometry. 3: ${ }^{19} \mathrm{~F}\left(\mathrm{CDCl}_{3}\right): \delta-131.73\left(8 \mathrm{~F}, \mathrm{~m}\right.$ br, $\left.\mathrm{F}_{\text {ortho }}\right)-142.68$ $\left(4 \mathrm{~F}, \mathrm{t},{ }^{3} J_{\mathrm{FF}}=21.0 \mathrm{~Hz}, \mathrm{~F}_{\text {meta }}\right),-159.46\left(8 \mathrm{~F}, \mathrm{~m}, \mathrm{~F}_{\text {para }}\right) .{ }^{31} \mathrm{P}\left\{{ }^{1} \mathrm{H}\right\}$ $\left(\mathrm{CDCl}_{3}\right): \delta 15.0\left(\mathrm{~d},{ }^{3} J_{\mathrm{PP}}=78 \mathrm{~Hz}, \mathrm{PO}\right),-60.1$ (dquintquint, ${ }^{3} J_{\mathrm{PP}}$ $\left.=78 \mathrm{~Hz},{ }^{3} J_{\mathrm{PF}}=34 \mathrm{~Hz},{ }^{5} J_{\mathrm{PF}}=10 \mathrm{~Hz}, \mathrm{P}\right) .4:{ }^{1} \mathrm{H} \mathrm{NMR}\left(\mathrm{CDCl}_{3}\right)$ : $\delta 4.02\left(4 \mathrm{~F}, \mathrm{t},{ }^{2} J_{\mathrm{PH}}=14.9 \mathrm{~Hz}\right) .{ }^{19} \mathrm{~F} \mathrm{NMR}\left(\mathrm{CDCl}_{3}\right): \delta-132.22$ $\left(8 \mathrm{~F}, \mathrm{~m}, \mathrm{~F}_{\text {ortho }}\right),-142.28\left(4 \mathrm{~F}, \mathrm{t},{ }^{2} J_{\mathrm{FF}}=20.4 \mathrm{~Hz}, \mathrm{~F}_{\text {para }}\right),-157.70$ $\left(8 \mathrm{~F}, \mathrm{~m}, \mathrm{~F}_{\text {meta }}\right) .{ }^{31} \mathrm{P}\left\{{ }^{1} \mathrm{H}\right\} \mathrm{NMR}\left(\mathrm{CDCl}_{3}\right): \delta 8.9(\mathrm{~s}) . \mathrm{LSIMS}, \mathrm{m} / \mathrm{z}$ (rel int): $776\left(63 \%, \mathrm{M}^{+}\right), 609\left(100 \%,\left[\mathrm{M}-\mathrm{C}_{6} \mathrm{~F}_{5}\right]^{+}\right)$. HRLSIMS: calcd for $\mathrm{C}_{25} \mathrm{H}_{2} \mathrm{~F}_{20} \mathrm{O}_{2} \mathrm{P}_{2}, 775.9210$; found $\mathrm{M}^{+}$, 775.9220.

$\left[\mathbf{C p} * \mathbf{R h C l}\left\{\kappa \boldsymbol{P}, \kappa \boldsymbol{P}-\left(\mathbf{C}_{6} \mathbf{F}_{5}\right)_{2} \mathbf{P C H}_{2} \mathbf{P}\left(\mathbf{C}_{6} \mathbf{F}_{5}\right)_{2}\right\}\right] \mathbf{B F}_{4}(\mathbf{5}) .[\mathrm{Cp} * \mathrm{RhCl}-$ $(\mu-\mathrm{Cl})]_{2}(0.068 \mathrm{~g}, 0.11 \mathrm{mmol}), 2(0.149 \mathrm{~g}, 0.2 \mathrm{mmol})$, and $\mathrm{NaBF}_{4}$ $(0.52 \mathrm{~g}, 4.7 \mathrm{mmol})$ were treated as for the synthesis of [Cp*RhCl$\left.\left\{\left(\mathrm{C}_{6} \mathrm{~F}_{5}\right)_{2} \mathrm{PCH}_{2} \mathrm{CH}_{2} \mathrm{P}\left(\mathrm{C}_{6} \mathrm{~F}_{5}\right)_{2}\right\}\right]\left[\mathrm{BF}_{4}\right] .{ }^{48}$ Salt $\mathbf{5}$ was obtained as an orange solid $(0.187 \mathrm{~g}, 92 \%) .{ }^{1} \mathrm{H}$ NMR $\left(\left(\mathrm{CD}_{3}\right)_{2} \mathrm{CO}\right): \delta 5.66(1 \mathrm{H}$, $\left.\mathrm{m}, \mathrm{C} H \mathrm{H}^{\prime}\right), 4.93\left(1 \mathrm{H}, \mathrm{m}, \mathrm{CH} H^{\prime}\right), 1.78\left(15 \mathrm{H}, \mathrm{t},{ }^{4} J_{\mathrm{PH}}=6.1 \mathrm{~Hz}\right.$, $\left.\mathrm{C}_{5} \mathrm{Me}_{5}\right) .{ }^{19} \mathrm{~F} \mathrm{NMR}\left(\left(\mathrm{CD}_{3}\right)_{2} \mathrm{CO}\right): \delta-128.71$ (4F, br, $\left.\mathrm{F}_{\text {ortho }}\right),-130.31$ $\left(4 \mathrm{~F}, \mathrm{br}, \mathrm{F}_{\text {ortho }}\right),-145.90\left(2 \mathrm{~F}, \mathrm{t},{ }^{3} J_{\mathrm{FF}}=20.3 \mathrm{~Hz}, \mathrm{~F}_{\text {para }}\right),-147.42$ $\left(2 \mathrm{~F}, \mathrm{t},{ }^{2} J_{\mathrm{FF}}=20.3 \mathrm{~Hz}, \mathrm{~F}_{\text {para }}\right),-152.54\left(0.8 \mathrm{~F},{ }^{10} \mathrm{BF}_{4}\right),-152.60(3.2 \mathrm{~F}$, $\left.{ }^{11} \mathrm{BF}_{4}\right),-159.81\left(4 \mathrm{~F}, \mathrm{br}, \mathrm{F}_{\text {meta }}\right),-161.16\left(4 \mathrm{~F}, \mathrm{br}, \mathrm{F}_{\text {meta }}\right) .{ }^{31} \mathrm{P}\left\{{ }^{1} \mathrm{H}\right\}$ NMR $\left(\left(\mathrm{CD}_{3}\right)_{2} \mathrm{CO}\right): \delta-34.0\left(\mathrm{dm},{ }^{1} J_{\mathrm{RhP}}=132 \mathrm{~Hz}\right)$. LSIMS, $\mathrm{m} / \mathrm{z}$ : $1017\left(100 \%,\left[\mathrm{M}-\mathrm{BF}_{4}\right]^{+}\right), 982\left(23 \%,\left[\mathrm{M}-\mathrm{BF}_{4}-\mathrm{Cl}\right]^{+}\right)$. HRLSIMS: calcd for $\mathrm{C}_{35} \mathrm{H}_{17}{ }^{35} \mathrm{ClF}_{20} \mathrm{P}_{2} \mathrm{Rh}, 1016.9237$; found $\mathrm{M}^{+}$, 1016.9229. Anal. Calcd for $\mathrm{C}_{35} \mathrm{H}_{17} \mathrm{BClF}_{24} \mathrm{P}_{2} \mathrm{Rh}$ : C, 38.00; $\mathrm{H}, 1.54$. Found: C, 37.78; H, 1.44

$\left[\mathbf{C p} * \operatorname{IrCl}\left\{\kappa \boldsymbol{P}, \kappa \boldsymbol{P}-\left(\mathbf{C}_{6} \mathbf{F}_{5}\right)_{2} \mathbf{P C H}_{2} \mathbf{P}\left(\mathbf{C}_{6} \mathbf{F}_{5}\right)_{2}\right\}\right] \mathbf{B F}_{4}(\mathbf{6}) .[\mathrm{Cp} * \operatorname{IrCl}(\mu-$ $\mathrm{Cl})]_{2}(0.100 \mathrm{~g}, 0.134 \mathrm{mmol}), 2(0.187 \mathrm{~g}, 0.251 \mathrm{mmol})$, and $\mathrm{NaBF}_{4}$ $(0.119 \mathrm{~g}, 0.250 \mathrm{mmol})$ were treated as for the synthesis of salt $\mathbf{5}$. Salt 6 was obtained as a yellow solid $(0.203 \mathrm{~g}, 65.5 \%) .{ }^{1} \mathrm{H}$ NMR $\left(\left(\mathrm{CD}_{3}\right)_{2} \mathrm{CO}\right): \delta 5.75\left(1 \mathrm{H}, \mathrm{m}, \mathrm{CH} \mathrm{H}^{\prime}\right), 4.05\left(1 \mathrm{H}, \mathrm{m}, \mathrm{CH} H^{\prime}\right), 1.691$ $\left(15 \mathrm{H}, \mathrm{t},{ }^{4} \mathrm{~J}_{\mathrm{PH}}=3.9 \mathrm{~Hz}, \mathrm{C}_{5} \mathrm{Me}_{5}\right) .{ }^{19} \mathrm{~F}$ NMR $\left(\left(\mathrm{CD}_{3}\right)_{2} \mathrm{CO}\right): \delta-128.23$ $\left(4 \mathrm{~F}\right.$, br, $\left.\mathrm{F}_{\text {ortho }}\right),-130.04\left(4 \mathrm{~F}, \mathrm{br}, \mathrm{F}_{\text {ortho }}\right),-140.46\left(2 \mathrm{~F}, \mathrm{t},{ }^{3} J_{\mathrm{FF}}=\right.$ $\left.20.6 \mathrm{~Hz}, \mathrm{~F}_{\text {para }}\right),-142.42\left(2 \mathrm{~F}, \mathrm{t},{ }^{3} J_{\mathrm{FF}}=20.7 \mathrm{~Hz}, \mathrm{~F}_{\text {para }}\right),-154.80$ $\left(0.8 \mathrm{~F},{ }^{10} \mathrm{BF}_{4}\right),-154.86\left(3.2 \mathrm{~F},{ }^{11} \mathrm{BF}_{4}\right),-155.72\left(4 \mathrm{~F}, \mathrm{~m}, \mathrm{~F}_{\text {meta }}\right)$, $-157.22\left(2 \mathrm{~F}\right.$, br, $\left.\mathrm{F}_{\text {meta }}\right),-157.80\left(2 \mathrm{~F}\right.$, br, $\left.\mathrm{F}_{\text {meta }}\right) .{ }^{31} \mathrm{P}\left\{{ }^{1} \mathrm{H}\right\}$ NMR $\left(\left(\mathrm{CD}_{3}\right)_{2} \mathrm{CO}\right): \delta-73.1$ (s). LSIMS, $m / z: 1107$ (100\%, [M $\left.\left.\mathrm{BF}_{4}\right]^{+}\right), 1072\left(8 \%,\left[\mathrm{M}-\mathrm{BF}_{4}-\mathrm{Cl}\right]^{+}\right)$. HRLSIMS: calcd for $\mathrm{C}_{35} \mathrm{H}_{17}{ }^{35} \mathrm{ClF}_{20} \mathrm{P}_{2}{ }^{193} \mathrm{Ir}$, 1106.9803; found $\mathrm{M}^{+}$, 1106.9846. Anal. Calcd for $\mathrm{C}_{35} \mathrm{H}_{17} \mathrm{BClF}_{24} \mathrm{P}_{2} \mathrm{Ir}$ : C, 35.20; H, 1.42. Found: C, 34.53; $\mathrm{H}, 1.58$.

$\left[\left(\eta^{6}\right.\right.$ - $p$-Cymene $\left.) \operatorname{RuCl}\left\{\kappa \boldsymbol{P}, \kappa P-\left(\mathbf{C}_{6} \mathbf{F}_{5}\right)_{2} \mathbf{P C H}_{2} \mathbf{P}\left(\mathbf{C}_{6} \mathbf{F}_{5}\right)_{2}\right\}\right] \mathrm{BF}_{4} \quad$ (7). $\left[\left(\eta^{6}-p \text {-Cymene }\right) \operatorname{RuCl}(\mu-\mathrm{Cl})\right]_{2}(0.100 \mathrm{~g}, 0.163 \mathrm{mmol}), 2$ (0.243 g, $0.326 \mathrm{mmol})$, and $\mathrm{NaBF}_{4}(0.06 \mathrm{~g}, 0.601 \mathrm{mmol})$ were treated as for the synthesis of salt $\mathbf{5}$. Salt $\mathbf{7}$ was obtained as an orange solid and was recrystallized from acetone $(0.330 \mathrm{~g}, 91.9 \%) .{ }^{1} \mathrm{H}$ NMR $\left(\mathrm{CD}_{3} \mathrm{Cl}\right): \delta 6.27\left(2 \mathrm{H}, \mathrm{d},{ }^{3} J_{\mathrm{HH}}=6.9 \mathrm{~Hz}, \mathrm{C}_{6} \mathrm{H}_{4}\right), 6.09\left(2 \mathrm{H}, \mathrm{d},{ }^{2} J_{\mathrm{HH}}\right.$ $=6.9 \mathrm{~Hz}, \mathrm{CH}), 4.92\left(1 \mathrm{H}, \mathrm{m}, \mathrm{CH} \mathrm{H}^{\prime}\right), 4.01\left(1 \mathrm{H}, \mathrm{m}, \mathrm{CH} H^{\prime}\right), 2.58$ $\left(1 \mathrm{H}\right.$, sept, $\left.{ }^{3} \mathrm{~J}_{\mathrm{HH}}=6.8 \mathrm{~Hz}, \mathrm{CH}\left(\mathrm{CH}_{3}\right)_{2}\right), 1.89\left(3 \mathrm{H}, \mathrm{s}, \mathrm{CH}_{3}\right), 1.16(6 \mathrm{H}$, $\left.\mathrm{d},{ }^{3} J_{\mathrm{HH}}=6.8 \mathrm{~Hz} \mathrm{CH}\left(\mathrm{CH}_{3}\right)_{2}\right) \cdot{ }^{19} \mathrm{~F} \mathrm{NMR}\left(\mathrm{CD}_{3} \mathrm{Cl}\right): \delta-128.95(4 \mathrm{~F}$, br, $\left.\mathrm{F}_{\text {ortho }}\right),-129.76\left(4 \mathrm{~F}\right.$, br, $\left.\mathrm{F}_{\text {ortho }}\right),-145.94\left(2 \mathrm{~F}, \mathrm{t},{ }^{3} J_{\mathrm{FF}}=20.5 \mathrm{~Hz}\right.$,
$\left.\mathrm{F}_{\text {para }}\right),-147.98\left(2 \mathrm{~F}, \mathrm{t},{ }^{3} J_{\mathrm{FF}}=20.0 \mathrm{~Hz}, \mathrm{~F}_{\text {para }}\right),-153.31\left(0.8 \mathrm{~F},{ }^{10} \mathrm{BF}_{4}\right)$, $-153.36\left(3.2 \mathrm{~F},{ }^{11} \mathrm{BF}_{4}\right),-159.08\left(4 \mathrm{~F}, \mathrm{~m}, \mathrm{~F}_{\text {meta }}\right),-161.23(2 \mathrm{~F}, \mathrm{br}$, $\left.\mathrm{F}_{\text {meta }}\right),-162.01\left(2 \mathrm{~F}\right.$, br, $\left.\mathrm{F}_{\text {meta }}\right) .{ }^{31} \mathrm{P}\left\{{ }^{1} \mathrm{H}\right\}$ NMR $\left(\mathrm{CD}_{3} \mathrm{Cl}\right): \delta-27.0$ (s). ESMS, $m / z: 1015\left(100 \%,\left[\mathrm{M}-\mathrm{BF}_{4}\right]^{+}\right), 881\left(9 \%,\left[\mathrm{M}-\mathrm{BF}_{4}\right.\right.$ $-\mathrm{Cl}]^{+}$). HRESMS: calcd for $\mathrm{C}_{34} \mathrm{H}_{16}{ }^{35} \mathrm{ClF}_{20} \mathrm{P}_{2}{ }^{102} \mathrm{Ru}, 1014.9140$; found $\mathrm{M}^{+}$, 1014.9141. Anal. Calcd for $\mathrm{C}_{35} \mathrm{H}_{16} \mathrm{BClF}_{24} \mathrm{P}_{2} \mathrm{Ru}$ : $\mathrm{C}$, 38.13; H, 1.45. Found: C, 37.35; H, 2.77.

$\left[\left(\eta^{6}\right.\right.$-Mesitylene $\left.) \operatorname{RuCl}\left\{\kappa P, \kappa P-\left(\mathbf{C}_{6} \mathbf{F}_{5}\right)_{2} \mathbf{P C H}_{2} \mathbf{P}\left(\mathbf{C}_{6} \mathbf{F}_{5}\right)_{2}\right\}\right] \mathrm{BF}_{4}(\mathbf{8})$. $\left[\left(\eta^{6} \text {-Mesitylene }\right) \mathrm{RuCl}(\mu-\mathrm{Cl})\right]_{2}(0.190 \mathrm{~g}, 0.30 \mathrm{mmol}), 2(0.446 \mathrm{~g}$, $0.60 \mathrm{mmol})$, and $\mathrm{NaBF}_{4}(0.132 \mathrm{~g}, 1.20 \mathrm{mmol})$ were treated as for the synthesis of salt $\mathbf{5}$. Salt $\mathbf{8}$ was obtained as a green solid and was recrystallized from dichloromethane $(0.600 \mathrm{~g}, 91.9 \%) .{ }^{1} \mathrm{H}$ NMR $\left(\mathrm{CD}_{3} \mathrm{Cl}\right): \delta 6.38\left(1 \mathrm{H}, \mathrm{m}, \mathrm{CH} \mathrm{H}^{\prime}\right), 5.91\left(3 \mathrm{H}, \mathrm{s}, \mathrm{C}_{6} \mathrm{H}_{3}\right), 5.34(2 \mathrm{H}, \mathrm{s}$, $\left.\mathrm{CH}_{2} \mathrm{Cl}_{2}\right), 4.77\left(1 \mathrm{H}, \mathrm{m}, \mathrm{CH} H^{\prime}\right), 2.30\left(9 \mathrm{H}, \mathrm{s}, \mathrm{C}_{6} \mathrm{Me}_{3}\right) .{ }^{19} \mathrm{~F}$ NMR $\left(\mathrm{CD}_{3} \mathrm{Cl}\right): \delta-125.78\left(4 \mathrm{~F}\right.$, br, $\left.\mathrm{F}_{\text {ortho }}\right),-129.82\left(4 \mathrm{~F}\right.$, br, $\left.\mathrm{F}_{\text {ortho }}\right)$, $-139.20\left(2 \mathrm{~F}, \mathrm{t},{ }^{3} J_{\mathrm{FF}}=21.0 \mathrm{~Hz}, \mathrm{~F}_{\text {para }}\right),-142.69\left(2 \mathrm{~F}, \mathrm{t},{ }^{2} J_{\mathrm{FF}}=20.5\right.$ $\left.\mathrm{Hz}, \mathrm{F}_{\text {para }}\right),-152.79\left(0.8 \mathrm{~F},{ }^{10} \mathrm{BF}_{4}\right),-152.84\left(3.2 \mathrm{~F},{ }^{11} \mathrm{BF}_{4}\right),-154.41$ $\left(4 \mathrm{~F}, \mathrm{~m}, \mathrm{~F}_{\text {meta }}\right),-156.77\left(4 \mathrm{~F}, \mathrm{~m}, \mathrm{~F}_{\text {meta }}\right) .{ }^{31} \mathrm{P}\left\{{ }^{1} \mathrm{H}\right\} \mathrm{NMR}\left(\mathrm{CD}_{3} \mathrm{Cl}\right): \delta$ -25.4 (s). LSIMS, $m / z: 1001\left(100 \%,\left[\mathrm{M}-\mathrm{BF}_{4}\right]^{+}\right), 966(8 \%,[\mathrm{M}$ - $\left.\mathrm{BF}_{4}-\mathrm{Cl}\right]^{+}$). HRLSIMS: calcd for $\mathrm{C}_{34} \mathrm{H}_{14}{ }^{35} \mathrm{ClF}_{20} \mathrm{P}_{2}{ }^{102} \mathrm{Ru}$, 1000.8987; found $\mathrm{M}^{+}, 1000.8966$. Anal. Calcd for $\mathrm{C}_{35} \mathrm{H}_{14} \mathrm{BClF}_{24} \mathrm{P}_{2^{-}}$ Ru. $\mathrm{CH}_{2} \mathrm{Cl}_{2}$ : C, 35.83; H, 1.37. Found: C, 35.73; H, 1.41.

$\left[\left\{\left(\eta^{5}, \kappa P-\mathrm{C}_{5} \mathbf{M e}_{4} \mathbf{C H}_{2} \mathrm{C}_{6} \mathbf{F}_{4}-\mathbf{2}-\mathbf{P}\left(\mathbf{C}_{6} \mathbf{F}_{5}\right) \mathbf{C H}_{2} \mathbf{P}\left(\mathbf{C}_{6} \mathbf{F}_{5}\right)_{2}\right\} \mathbf{R h C l}_{2}\right](9)\right.$. A slurry of $[\mathrm{Cp} * \mathrm{RhCl}(\mu-\mathrm{Cl})]_{2}(0.141 \mathrm{~g}, 0.23 \mathrm{mmol})$ and $2(0.312 \mathrm{~g}$, $0.42 \mathrm{mmol})$ in benzene $\left(100 \mathrm{~cm}^{3}\right)$ was heated at reflux for $95 \mathrm{~h}$. After cooling, the solution was concentrated to ca. $50 \mathrm{~cm}^{3}$ by rotary evaporation and hexane $\left(50 \mathrm{~cm}^{3}\right)$ added. The resulting red-brown precipitate was filtered off, washed with hot hexane $\left(3 \times 10 \mathrm{~cm}^{3}\right)$, and dried in vacuo $(0.285 \mathrm{~g}, 70 \%) .{ }^{1} \mathrm{H}$ NMR $\left(\left(\mathrm{CD}_{3}\right)_{2} \mathrm{CO}\right): \delta 5.15$ $\left(1 \mathrm{H}, \mathrm{dd},{ }^{2} J_{\mathrm{PH}}=14.3 \mathrm{~Hz},{ }^{2} J_{\mathrm{HH}^{\prime}}=14.3 \mathrm{~Hz}, \mathrm{PCHH} \mathrm{P}\right), 4.35(1 \mathrm{H}, \mathrm{dd}$, $\left.{ }^{2} J_{\mathrm{PH}^{\prime}}=14.3 \mathrm{~Hz},{ }^{2} J_{\mathrm{HH}^{\prime}}=14.3 \mathrm{~Hz}, \mathrm{PCH} H^{\prime} \mathrm{P}\right), 4.18\left(1 \mathrm{H}, \mathrm{dd},{ }^{2} J_{\mathrm{HH}^{\prime}}=\right.$ $\left.18.6 \mathrm{~Hz},{ }^{2} J_{\mathrm{PH}}=6.1 \mathrm{~Hz}, 1 \mathrm{H}, \mathrm{C}_{5} \mathrm{CHH}^{\prime} \mathrm{C}_{6} \mathrm{~F}_{4}\right), 3.96\left(1 \mathrm{H}, \mathrm{d},{ }^{2} J_{\mathrm{HH}^{\prime}}=\right.$ $\left.18.6 \mathrm{~Hz}, \mathrm{C}_{5} \mathrm{CH}^{\prime} \mathrm{C}_{6} \mathrm{~F}_{4}\right), 1.94\left(3 \mathrm{H}, \mathrm{d},{ }^{4} J_{\mathrm{PH}}=7.6 \mathrm{~Hz}, \mathrm{CH}_{3}\right), 1.86$ $\left(3 \mathrm{H}, \mathrm{d},{ }^{4} J_{\mathrm{P}, \mathrm{H}}=5.6 \mathrm{~Hz}, \mathrm{CH}_{3}\right), 1.83\left(3 \mathrm{H}, \mathrm{s}, \mathrm{CH}_{3}\right), 1.40\left(3 \mathrm{H}, \mathrm{d},{ }^{4} J_{\mathrm{PH}}\right.$ $\left.=0.9 \mathrm{~Hz}, \mathrm{CH}_{3}\right) \cdot{ }^{19} \mathrm{~F}$ NMR $\left(\left(\mathrm{CD}_{3}\right)_{2} \mathrm{CO}\right): \delta-121.25(1 \mathrm{~F}, \mathrm{~m})$, $-129.61(2 \mathrm{~F}, \mathrm{~m}),-130.14(2 \mathrm{~F}, \mathrm{~m}),-132.61$ (2F, m), -136.99 $(1 \mathrm{~F}, \mathrm{~m}),-149.29(1 \mathrm{~F}, \mathrm{td}, J=20.2 \mathrm{~Hz}, J=9.0 \mathrm{~Hz}),-150.26(1 \mathrm{~F}$, $\mathrm{m}),-152.23(1 \mathrm{~F}, \mathrm{~m}),-152.43(1 \mathrm{~F}, \mathrm{~m}),-158.43(1 \mathrm{~F}, \mathrm{t}, J=20.2$ $\mathrm{Hz}),-162.37$ (2F, m) $-163.02(2 \mathrm{~F}, \mathrm{~m}),-163.54(2 \mathrm{~F}, \mathrm{~m}) .{ }^{31} \mathrm{P}\left\{{ }^{1} \mathrm{H}\right\}$ NMR $\left(\left(\mathrm{CD}_{3}\right)_{2} \mathrm{CO}\right): \delta 43.1\left(\mathrm{ddm},{ }^{1} J_{\mathrm{RhP}}=170 \mathrm{~Hz},{ }^{2} J_{\mathrm{PP}}=185 \mathrm{~Hz}\right.$, $\left.\mathrm{PC}_{6} \mathrm{~F}_{4} \mathrm{CH}_{2}\right),-66.6$ (dquint, ${ }^{2} J_{\mathrm{PP}}=185 \mathrm{~Hz},{ }^{3} J_{\mathrm{PF}}=38 \mathrm{~Hz}, \mathrm{P}\left(\mathrm{C}_{6} \mathrm{~F}_{5}\right)_{2}$ ). LSIMS: $997\left(100 \%,[\mathrm{M}-\mathrm{Cl}]^{+}\right), 961\left(29 \%,[\mathrm{M}-2 \mathrm{Cl}]^{+}\right)$. HRLSIMS: calcd for $\mathrm{C}_{35} \mathrm{H}_{16}{ }^{35} \mathrm{ClF}_{19} \mathrm{P}_{2} \mathrm{Rh}$ 996.9167; found $\mathrm{M}^{+}$, 996.9173. Anal. Calcd for $\mathrm{C}_{35} \mathrm{H}_{16} \mathrm{Cl}_{2} \mathrm{~F}_{19} \mathrm{P}_{2} \mathrm{Rh} \cdot 1 / 2 \mathrm{CH}_{2} \mathrm{Cl}_{2}$ : C, 39.63; H, 1.59. Found: C, 40.65; H, 1.55 .

$\left[\left\{\left(\eta^{5}, \kappa P-\mathbf{C}_{5} \mathbf{M e}_{4} \mathbf{C H}_{2} \mathbf{C}_{6} \mathbf{F}_{4}-\mathbf{2}-\mathbf{P}\left(\mathbf{C}_{6} \mathbf{F}_{5}\right) \mathrm{CH}_{2} \mathbf{P}\left(\mathbf{C}_{6} \mathbf{F}_{5}\right)_{2}\right\} \mathbf{I r C l}_{2}\right](10)\right.$. A slurry of $[\mathrm{Cp} * \mathrm{IrCl}(\mu-\mathrm{Cl})]_{2}(0.106 \mathrm{~g}, 0.133 \mathrm{mmol})$ and $2(0.198 \mathrm{~g}$, $0.266 \mathrm{mmol})$ in benzene $\left(100 \mathrm{~cm}^{3}\right)$ was heated at reflux for $72 \mathrm{~h}$. After cooling, the solution was concentrated to ca. $50 \mathrm{~cm}^{3}$ by rotary evaporation and hexane $\left(50 \mathrm{~cm}^{3}\right)$ added. The resulting yellow precipitate was filtered off and washed with hot hexane $(3 \times 10$ $\left.\mathrm{cm}^{3}\right)$. The product was extracted into dichloromethane and the solution filtered through Celite. The solvent was removed by rotary evaporation and put through a Celite plug eluting with dichloromethane. The solvent was removed by rotary evaporation and the solid dried in vacuo, yielding $0.12 \mathrm{~g}$ of impure $\mathbf{1 0}$ as a yellow powder. All attempts to purify $\mathbf{1 0}$ were unsuccessful, and characterization is based on the mass spectral data and comparison of the NMR spectroscopic data with those of 9. ${ }^{1} \mathrm{H}$ NMR $\left(\mathrm{CD}_{3} \mathrm{Cl}\right)$ : $\delta$ $5.21\left(1 \mathrm{H}, \mathrm{ddm},{ }^{2} J_{\mathrm{PH}}=13.1 \mathrm{~Hz},{ }^{2} J_{\mathrm{HH}^{\prime}}=13.1 \mathrm{~Hz}, \mathrm{PC} H \mathrm{H}^{\prime} \mathrm{P}\right), 4.31$ $\left(1 \mathrm{H}, \mathrm{m}, \mathrm{PCH} H^{\prime} \mathrm{P}\right), 3.93\left(1 \mathrm{H}, \mathrm{dm},{ }^{2} J_{\mathrm{HH}^{\prime}}=18.7 \mathrm{~Hz}, 1 \mathrm{H}\right.$ $\left.\mathrm{C}_{5} \mathrm{CHH}^{\prime} \mathrm{C}_{6} \mathrm{~F}_{4}\right), 3.77\left(1 \mathrm{H}, \mathrm{dm},{ }^{2} J_{\mathrm{HH}^{\prime}}=18.7 \mathrm{~Hz}, \mathrm{C}_{5} \mathrm{CH}^{\prime} \mathrm{C}_{6} \mathrm{~F}_{4}\right), 1.91$ $\left(3 \mathrm{H}, \mathrm{d},{ }^{4} J_{\mathrm{PH}}=5.4 \mathrm{~Hz}, \mathrm{CH}_{3}\right), 1.84\left(3 \mathrm{H}, \mathrm{s}, \mathrm{CH}_{3}\right), 1.77\left(3 \mathrm{H}, \mathrm{d},{ }^{4} J_{\mathrm{P}, \mathrm{H}}\right.$ $\left.=4.2 \mathrm{~Hz}, \mathrm{CH}_{3}\right), 1.27\left(3 \mathrm{H}, \mathrm{d},{ }^{4} \mathrm{~J}_{\mathrm{PH}}=0.9 \mathrm{~Hz}, \mathrm{CH}_{3}\right) .{ }^{19} \mathrm{~F} \mathrm{NMR}$ $\left(\mathrm{CD}_{3} \mathrm{Cl}\right): \delta-121.20(1 \mathrm{~F}, \mathrm{~m}),-128.71(2 \mathrm{~F}, \mathrm{~m}),-129.67(2 \mathrm{~F}, \mathrm{~m})$, $-130.56(2 \mathrm{~F}, \mathrm{~m}),-135.86(1 \mathrm{~F}, \mathrm{~m}),-146.04(1 \mathrm{~F}, \mathrm{~m}),-146.58$ $(1 \mathrm{~F}, \mathrm{t}, J=20.3 \mathrm{~Hz}),-148.28(1 \mathrm{~F}, \mathrm{t}, J=20.6 \mathrm{~Hz}),-149.32(1 \mathrm{~F}$, 
Table 11. Crystal Data and Structure Refinement for Compounds $2,5,6,8 \cdot \mathrm{CH}_{2} \mathrm{Cl}_{2}$, 9, and 11

\begin{tabular}{|c|c|c|c|c|c|c|}
\hline & 2 & 5 & 6 & $\mathbf{8} \cdot \mathrm{CH}_{2} \mathrm{Cl}_{2}$ & 9 & 11 \\
\hline formula & $\mathrm{C}_{25} \mathrm{H}_{2} \mathrm{~F}_{20} \mathrm{P}_{2}$ & $\mathrm{C}_{35} \mathrm{H}_{17} \mathrm{BClF}_{24} \mathrm{P}_{2} \mathrm{Rh}$ & $\begin{array}{l}\mathrm{C}_{35} \mathrm{H}_{17} \mathrm{BClF}_{24^{-}} \\
\mathrm{P}_{2} \mathrm{Ir}\end{array}$ & $\begin{array}{l}\mathrm{C}_{34} \mathrm{H}_{14} \mathrm{BClF}_{24} \mathrm{P}_{2} \mathrm{Ru} \cdot \\
\mathrm{CH}_{2} \mathrm{Cl}_{2}\end{array}$ & $\begin{array}{c}\mathrm{C}_{35} \mathrm{H}_{16} \mathrm{Cl}_{2} \mathrm{~F}_{19^{-}} \\
\mathrm{P}_{2} \mathrm{Rh}\end{array}$ & $\begin{array}{c}\mathrm{C}_{34} \mathrm{H}_{14} \mathrm{Cl}_{4} \mathrm{~F}_{20^{-}} \\
\mathrm{P}_{2} \mathrm{Ru}_{2}\end{array}$ \\
\hline fw & 744.21 & 1104.60 & 1193.89 & 1172.65 & 1033.23 & 1208.33 \\
\hline cryst dimens, mm & $\begin{array}{l}0.62 \times 0.38 \times \\
0.20\end{array}$ & $\begin{array}{l}0.40 \times 0.22 \times \\
0.19\end{array}$ & $\begin{array}{l}0.64 \times 0.50 \times \\
0.34\end{array}$ & $\begin{array}{l}0.98 \times 0.28 \times \\
0.26\end{array}$ & $\begin{array}{l}0.56 \times 0.28 \times \\
0.26\end{array}$ & $\begin{array}{c}0.31 \times 0.12 \times \\
0.10\end{array}$ \\
\hline$T, \mathrm{~K}$ & $153(2)$ & $298(2)$ & $298(2)$ & $153(2)$ & $153(2)$ & $298(2)$ \\
\hline cryst syst & triclinic & orthorhombic & orthorhombic & monoclinic & orthorhombic & triclinic \\
\hline $\begin{array}{l}\text { space group } \\
\text { unit cell dimens }\end{array}$ & $P \overline{1}$ & Pna2(1) & Pnma & $\mathrm{P} 2{ }_{1} / c$ & Pna2(1) & $P \overline{1}$ \\
\hline$a, \AA$ & $10.440(3)$ & $17.933(3)$ & $17.95(4)$ & $15.047(2)$ & $14.6421(13)$ & $10.410(4)$ \\
\hline$b, \AA$ & $11.061(3)$ & $9.7034(16)$ & $21.60(5$ & $12.572(2)$ & $12.4541(11)$ & $11.037(5)$ \\
\hline$c, \AA$ & $12.053(3)$ & $21.676(4)$ & $9.71(2)$ & $21.976(4)$ & $19.7153(17)$ & $18.457(7)$ \\
\hline$\alpha, \operatorname{deg}$ & $82.896(4)$ & 90 & 90 & 90 & 90 & $104.793(6)$ \\
\hline$\beta, \operatorname{deg}$ & $67.141(4)$ & 90 & 90 & $109.372(3)$ & 90 & $92.372(6)$ \\
\hline$\gamma, \mathrm{deg}$ & $80.910(4)$ & 90 & 90 & 90 & 90 & $104.433(6)$ \\
\hline$V, \AA^{3}$ & $1263.5(5)$ & $3771.8(11)$ & $3765(14)$ & $3921.7(11)$ & $3595.2(5)$ & 1973.2(14) \\
\hline$Z$ & 2 & 4 & 4 & 4 & 4 & 2 \\
\hline calc density, $\mathrm{g} \mathrm{cm}^{-3}$ & 1.956 & 1.945 & 2.106 & 1.986 & 1.909 & 2.034 \\
\hline$F(000)$ & 724 & 2160 & 2288 & 2288 & 2024 & 1168 \\
\hline$\theta, \operatorname{deg}$ & $1.84-28.89$ & $2.56-24.99$ & $1.89-28.29$ & $1.43-28.35$ & $1.93-28.28$ & $1.15-25.00$ \\
\hline abs coeff, $\mathrm{mm}^{-1}$ & 0.339 & 0.758 & 3.851 & 0.831 & 0.841 & 1.241 \\
\hline total no. of data & 14325 & 31277 & 8755 & 44514 & 40403 & 14571 \\
\hline $\begin{array}{l}\text { no. of unique } \\
\text { data, } R_{\text {int }}\end{array}$ & $5531,0.0879$ & $6608,0.0353$ & $4020,0.2562$ & $9092,0.1307$ & $8342,0.0753$ & $6927,0.1009$ \\
\hline $\begin{array}{l}\text { final } R \text { indices } \\
\qquad[I>2 \sigma(I)]\end{array}$ & $R_{1}=0.0426$ & $R_{1}=0.0499$ & $R_{1}=0.1139$ & $R_{1}=0.0665$ & $R_{1}=0.0447$ & $R_{1}=0.0815$ \\
\hline & $w R_{2}=0.1034$ & $w R_{2}=0.1254$ & $w R_{2}=0.1633$ & $w R_{2}=0.1452$ & $w R_{2}=0.0856$ & $w R_{2}=0.1883$ \\
\hline$R$ indices (all data) & $\begin{array}{l}R_{1}=0.0648 \\
w R_{2}=0.1124\end{array}$ & $\begin{array}{l}R_{1}=0.0626 \\
w R_{2}=0.1387\end{array}$ & $\begin{array}{l}R_{1}=0.2497 \\
w R_{2}=0.2736\end{array}$ & $\begin{array}{l}R_{1}=0.1470 \\
w R_{2}=0.1849\end{array}$ & $\begin{array}{l}R_{1}=0.0705 \\
w R_{2}=0.0955\end{array}$ & $\begin{array}{l}R_{1}=0.1857 \\
w R_{2}=0.2547\end{array}$ \\
\hline GoF on $F^{2}$ & 1.034 & 1.029 & 1.082 & 1.009 & 1.017 & 0.919 \\
\hline $\begin{array}{l}\text { largest diff peak } \\
\text { and hole, } \mathrm{e} \AA^{-3}\end{array}$ & $0.420,-0.365$ & $1.845,-0.598$ & $5.517,-4.844$ & $1.901,-0.932$ & $1.308,-1.216$ & $1.468,-1.095$ \\
\hline Flack param & & 0.00 & & & $0.61(3)$ & \\
\hline
\end{tabular}

$\mathrm{t}, J=20.5 \mathrm{~Hz}),-155.73(1 \mathrm{~F}, \mathrm{t}, J=21.7 \mathrm{~Hz}),-159.36$ $(2 \mathrm{~F}, \mathrm{~m}),-160.06(4 \mathrm{~F}, \mathrm{~m}) .{ }^{31} \mathrm{P}\left\{{ }^{1} \mathrm{H}\right\}$ NMR $\left(\mathrm{CD}_{3} \mathrm{Cl}\right): \delta 11.0$ $\left(\mathrm{dm},{ }^{2} J_{\mathrm{PP}}=181 \mathrm{~Hz}, \mathrm{PC}_{6} \mathrm{~F}_{4} \mathrm{CH}_{2}\right),-69.2$ (dquint, ${ }^{2} J_{\mathrm{PP}}=181 \mathrm{~Hz}$, $\left.{ }^{3} J_{\mathrm{PF}}=35 \mathrm{~Hz}, \mathrm{P}\left(\mathrm{C}_{6} \mathrm{~F}_{5}\right)_{2}\right)$. LSIMS: $1087\left(100 \%,[\mathrm{M}-\mathrm{Cl}]^{+}\right)$. HRLSIMS: calcd for $\mathrm{C}_{35} \mathrm{H}_{16}{ }^{35} \mathrm{ClF}_{19} \mathrm{P}_{2}{ }^{191} \operatorname{Ir} 1084.97500$; found $\mathrm{M}^{+}$, 1084.971845 .

$\left[\left(\eta^{6}\right.\right.$-Mesitylene $) \operatorname{Ru}(\mu-\mathrm{Cl})_{3} \mathbf{R u C l}\left\{\kappa \boldsymbol{P}, \kappa P-\left(\mathbf{C}_{6} \mathbf{F}_{5}\right)_{2} \mathbf{P C H}{ }_{2} \mathbf{P}-\right.$ $\left.\left.\left(\mathbf{C}_{\mathbf{6}} \mathbf{F}_{\mathbf{5}}\right)_{2}\right\}\right]$ (11). A solution of $\left[\left(\eta^{6} \text {-mesitylene }\right) \operatorname{RuCl}(\mu-\mathrm{Cl})\right]_{2}(0.100$ $\mathrm{g}, 0.17 \mathrm{mmol})$ and $2(0.254 \mathrm{~g}, 0.34 \mathrm{mmol})$ in dichloromethane $(20$ $\left.\mathrm{cm}^{3}\right)$ and methanol $\left(70 \mathrm{~cm}^{3}\right)$ was heated at reflux for $20 \mathrm{~h}$. The solvent was removed by rotary evaporation and the resulting brown solid extracted with dichloromethane $\left(3 \times 20 \mathrm{~cm}^{3}\right)$. The extract was filtered and concentrated to $20 \mathrm{~cm}^{3}$ by rotary evaporation. Addition of diethyl ether $\left(10 \mathrm{~cm}^{3}\right)$ precipitated the product as a brown solid $(0.342 \mathrm{~g}, 95.8 \%) .{ }^{1} \mathrm{H}$ NMR $\left(\mathrm{CD}_{3} \mathrm{Cl}\right): \delta 6.26(1 \mathrm{H}, \mathrm{m}$, $\left.\mathrm{CHH}^{\prime}\right), 5.08\left(3 \mathrm{H}, \mathrm{s}, \mathrm{C}_{6} \mathrm{H}_{3}\right), 5.04\left(1 \mathrm{H}, \mathrm{m}, \mathrm{CH} H^{\prime}\right), 2.02(9 \mathrm{H}, \mathrm{s}$, $\left.\mathrm{C}_{6} \mathrm{Me}_{3}\right) .{ }^{19} \mathrm{~F} \mathrm{NMR}\left(\mathrm{CD}_{3} \mathrm{Cl}\right): \delta-128.18\left(8 \mathrm{~F}, \mathrm{~m}, \mathrm{~F}_{\text {ortho }}\right),-147.46$ (4F, m, $\left.\mathrm{F}_{\text {para }}\right),-159.62\left(4 \mathrm{~F}, \mathrm{~m}, \mathrm{~F}_{\text {meta }}\right) .{ }^{31} \mathrm{P}\left\{{ }^{1} \mathrm{H}\right\} \mathrm{NMR}\left(\mathrm{CD}_{3} \mathrm{Cl}\right): \delta$ -11.3 (s). LSIMS, m/z: $1209\left(100 \%,[\mathrm{M}-\mathrm{Cl}]^{+}\right), 1172(70 \%,[\mathrm{M}$ $-2 \mathrm{Cl}]^{+}$). HRLSIMS: calcd for $\mathrm{C}_{34} \mathrm{H}_{14}{ }^{35} \mathrm{Cl}_{3} \mathrm{~F}_{20} \mathrm{P}_{2}{ }^{102} \mathrm{Ru}_{2}, 1207.7087$; found $\mathrm{M}^{+}$, 1207.7085. Anal. Calcd for $\mathrm{C}_{34} \mathrm{H}_{14} \mathrm{Cl}_{4} \mathrm{~F}_{20} \mathrm{P}_{2} \mathrm{Ru}_{2}$ : $\mathrm{C}$, 33.77; H, 1.16. Found: C, 33.93; H, 1.24.

X-ray Crystallography. Crystals of $\left(\mathrm{C}_{6} \mathrm{~F}_{5}\right)_{2} \mathrm{PCH}_{2} \mathrm{P}\left(\mathrm{C}_{6} \mathrm{~F}_{5}\right)_{2}$ (2) were grown from petroleum ether (bp $\left.40-60{ }^{\circ} \mathrm{C}\right),[\mathrm{Cp} * \mathrm{RhCl}(\kappa P, \kappa P$ 2) $\mathrm{BF}_{4}(5)$ from chloroform, $[\mathrm{Cp} * \operatorname{IrCl}(\kappa P, \kappa P-2)] \mathrm{BF}_{4}(\mathbf{6})$ and $\left[\left(\eta^{6}-\right.\right.$ mesitylene $) \mathrm{RuCl}(\kappa P, \kappa P-2)] \mathrm{BF}_{4}(\mathbf{8})$ from dichloromethane, $\left[\left\{\left(\eta^{5}, \kappa P-\right.\right.\right.$ $\left.\left.\mathrm{C}_{5} \mathrm{Me}_{4} \mathrm{CH}_{2} \mathrm{C}_{6} \mathrm{~F}_{4}-2-\mathrm{P}\left(\mathrm{C}_{6} \mathrm{~F}_{5}\right) \mathrm{CH}_{2} \mathrm{P}\left(\mathrm{C}_{6} \mathrm{~F}_{5}\right)_{2}\right\} \mathrm{RhCl}_{2}\right](9)$ from dichloromethane/ hexane, and $\left[\left(\eta^{6}\right.\right.$-mesitylene $\left.) \operatorname{Ru}(\mu-\mathrm{Cl})_{3} \operatorname{RuCl}(\kappa P, \kappa P-\mathbf{1})\right](\mathbf{1 1})$ from propan-2-one. Crystal and refinement data are given in Table 11. Diffraction data were collected on a Bruker SMART diffractometer using the SAINT-NT ${ }^{60}$ software with graphite-monochromated Mo $\mathrm{K} \alpha$ radiation. Lorentz and polarization corrections were applied. Empirical absorption corrections were applied using SADABS. ${ }^{61}$

(60) SAINT-NT; Bruker AXS Inc.: Madison, WI, 1998.

(61) Sheldrick, G. M. SADABS; University of Göttingen: Germany 1996.
The structure was solved by direct methods and refined with the program package SHELXTL version 5. ${ }^{62}$ The non-hydrogen atoms were refined with anisotropic thermal parameters. Hydrogen atom positions were added, and idealized positions and a riding model with fixed thermal parameters $\left(U_{i j}=1.2 U_{\text {eq }}\right.$ for the atom to which they are bonded (1.5 for $\left.\mathrm{CH}_{3}\right)$ ) were used for subsequent refinements. The function minimized was $\sum\left[w\left(\left|F_{\mathrm{o}}\right|^{2}-\left|F_{\mathrm{c}}\right|^{2}\right)\right]$ with reflection weights $w^{-1}=\left[\sigma^{2}\left|F_{\mathrm{o}}\right|^{2}+(g 1 P)^{2}+(g 2 P)\right]$ where $P=$ $\left[\max \left|F_{\mathrm{o}}\right|^{2}+2\left|F_{\mathrm{c}}\right|^{2}\right] / 3 . \operatorname{CCDC} 633807(\mathbf{2}), 633810(\mathbf{5}), 633809(\mathbf{6})$, $633808(8), 294507$ (9), and 633811 (11) contain the supplementary crystallographic data for this paper. These data can be obtained free of charge from The Cambridge Crystallographic Data Centre via www.ccdc.cam.ac.uk/data_request/cif.

Catalyst Testing. Ketone Reduction, Substrate:Catalyst $=$ 100:1. The catalyst precursor $(0.01 \mathrm{mmol})$ was added to acetophenone $(0.12 \mathrm{~g}, 1 \mathrm{mmol})$ in propan-2-ol $(4.875 \mathrm{~mL})$, and the mixture was heated to $75^{\circ} \mathrm{C}$ under dinitrogen. Potassium hydroxide $(0.125$ $\mathrm{cm}^{3}, 0.1 \mathrm{M}$ in propan-2-ol) was added to the solution, which was left stirring at that temperature for the reaction time (usually $2 \mathrm{~h}$ ). The solution was filtered through a silica plug, eluting with ethyl acetate $\left(2 \times 5 \mathrm{~cm}^{3}\right)$. The solvent was removed by rotary evaporation to yield an acetophenone/phenyl alcohol mixture. The conversion was determined via ${ }^{1} \mathrm{H}$ NMR spectroscopy with the ratio between the methyl resonance exhibiting a singlet at $\delta 2.47$ for acetophenone and a doublet at $\delta 1.35$ for phenyl alcohol measured and given as a $\%$ conversion.

Ketone Reduction, Substrate:Catalyst $=1000: 1$. The catalyst precursor $(0.01 \mathrm{mmol})$ was added to acetophenone $(1.20 \mathrm{~g}, 10$ $\mathrm{mmol})$ in propan-2-ol $\left(4.875 \mathrm{~cm}^{3}\right)$, and the mixture was heated to $75{ }^{\circ} \mathrm{C}$ under dinitrogen. Potassium hydroxide $\left(0.125 \mathrm{~cm}^{3}, 0.1 \mathrm{M}\right.$ in propan-2-ol) was added to the solution, which was left stirring at that temperature for $2 \mathrm{~h}$. The solution was filtered through a silica plug, eluting with ethyl acetate $\left(2 \times 5 \mathrm{~cm}^{3}\right)$. The solvent was

(62) Sheldrick, G. M. SHELXTL version 5; Bruker AXS Inc.: Madison, WI, 1998. 
removed by rotary evaporation to yield an acetophenone/phenyl alcohol mixture. The conversion was determined via ${ }^{1} \mathrm{H}$ NMR spectroscopy with the ratio between the methyl resonance exhibiting a singlet at $\delta 2.47$ for acetophenone and a doublet at $\delta 1.35$ for phenyl alcohol measured and given as a \% conversion.

Alcohol (Oppenauer) Oxidation. The catalyst precursor (0.01 mmol) was added to rac-phenyl ethanol $(0.12 \mathrm{~g}, 0.1 \mathrm{mmol})$ in degassed propan-2-one $\left(4.875 \mathrm{~cm}^{3}\right)$ and stirred at $57{ }^{\circ} \mathrm{C}$ under dinitrogen. Potassium hydroxide $\left(0.125 \mathrm{~cm}^{3}, 0.1 \mathrm{M}\right.$ in propan-2-one) was added to the solution, which was left stirring at that temperature for $2 \mathrm{~h}$ under nitrogen. The solution was filtered through a silica plug, eluting with ethyl acetate $\left(2 \times 5 \mathrm{~cm}^{3}\right)$. The solvent was removed by rotary evaporation to yield an acetophenone/phenyl alcohol mixture. The conversion was determined via ${ }^{1} \mathrm{H}$ NMR spectroscopy with the ratio between the methyl resonance exhibiting a singlet at $\delta 2.47$ for acetophenone and doublet at $\delta 1.31-1.48$ for phenyl alcohol ${ }^{63}$ measured and given as a $\%$ conversion.

Acknowledgment. We thank the EU European Social Fund for funding (to C.L.P.), the EPSRC mass spectrometry service at Swansea, Prof. Paul Pringle of Bristol University, and Dr. Pete Licence of Nottingham University.

Supporting Information Available: A listing of atomic coordinates, anisotropic displacement parameters, bond distances, and bond angles for $\mathbf{2}, \mathbf{5}, \mathbf{6}, \mathbf{8} \cdot \mathrm{CH}_{2} \mathrm{Cl}_{2}, \mathbf{9}$, and $\mathbf{1 1}$. This material is available free of charge via the Internet at http://pubs.acs.org.

OM070089I

(63) Bianchi, D.; Cesti, P.; Bathstel, E. J. Org. Chem. 1988, 53, 5533. 